JACEK OŻÓG (Kraków)

\title{
Warunek si navis ex Asia venerit w starożytności i średniowieczu
}

W rzymskich tekstach prawnych, z których można poznać opinie jurysprudencji będące świadectwem rozważania problematyki dodatkowych zastrzeżeń umownych (accidentalia negotii), przede wszystkim w „Digestach” justyniańskich, częstokroć zauważyć można występowanie enigmatycznie brzmiącego warunku si navis ex Asia venerit ${ }^{1}$. Marginalne uwagi poświęcili mu już tacy przedstawiciele światowej romanistyki jak Tony Honoré ${ }^{2}$, Alan Rodger ${ }^{3}$ i Reinhard Zimmermann ${ }^{4}$. Niniejszy artykuł ma za zadanie prześledzić historyczny, „zewnętrzny” aspekt jego użycia przez autorów dostępnych nam źródeł. Wychodząc od kwestii chronologicznej, należy ustalić - na ile to możliwe - kto pierwszy posłużył się zwrotem si navis... oraz w jakim stopniu wpływ na przyjęcie takiego konkretnego sformułowania miały kwestie ekonomiczne i społeczne. Należy już w tym momencie zauważyć, że sformalizowane posługiwanie się określonym słownictwem może prowadzić do jego petryfikacji i oderwania się od pierwotnego podłoża jego funkcjonowania.

Teksty, w których użyto opisywanego warunku, dotykają całego spektrum tematów należących do różnych dziedzin prawa prywatnego. Niejeden z nich nadaje się do bycia przedmiotem odrębnego ujęcia monograficznego. Dlatego też będę odnosił się do nich, cały czas mając na względzie cel zarysowany na

1,Jeżeli statek przybędzie z Azji”. O ile nie zaznaczono inaczej, przekładu wszystkich tekstów zamieszczonych w niniejszej pracy dokonał autor. Selekcji łacińskich materiałów źródłowych pochodzących z „Digestów”, Fragmenta Vaticana i „Instytucji” Justyniana dokonano w oparciu o zasoby komputerowej bazy Bibliotheca Iuris Antiqui (BIA).

${ }^{2}$ It is a stock example. A.M. Honoré, Gaius, Oxford 1962.

${ }^{3}$ [F] amiliarity breeds contempt, and if there is one thing which has been familiar to generations of Roman Law students it is the ship from Asia, the navis quae venerit ex Asia. Its voyages to Italy have been just as inevitable a part of every Roman Law course as the Cornelian Farm and the island arising in a river. A. Rodger, Emptio Perfecta Revisited: a Study of Digest 18,6,8,1, TR 4 (1982), s. 337.

${ }^{4}$ With codification, the voyages of "the ship from Asia« as well as the ascents of countless stipulators up Capitol Hill have largely sunk into oblivion. R. Zimmermann, The Law of Obligations. Roman Foundations of Civilian Tradition, Oxford 1996, s. 743. 
początku niniejszego opracowania. $\mathrm{W}$ tym przypadku przedstawienie problemów dogmatycznych wyszczególnionych w wybranych fragmentach będzie kwestią zupełnie drugorzędną i stąd - o ile będzie to możliwe dla zachowania spójności wywodu - będę starał się unikać jakichkolwiek rozważań dogmatycznoprawnych. Niekiedy dla szerszego ujęcia zagadnienia istotny może być kontekst palingenetyczny, w jakim dane teksty występują.

I. Uwarunkowania społeczno-historyczne użycia warunku. Słowo „Azja” od niepamiętnych czasów oznaczało coś więcej niż tylko zamkniętą w dość wąskich granicach administracyjnych prowincję utworzoną przez Rzym w 129 roku przed Chr. wskutek wykonania pochodzaceego z roku 133 testamentu Attalosa III, króla Pergamonu. Etymologia tego terminu nie jest dokładnie poświadczona - być może prowadzi do akadyjskiego (w)asu(m) (,wychodzić”, „wstępować”), które jest spokrewnione z fenickim asa („wschód”). Badacze zwracają także uwage na syryjskie pojęcie asu jako przeciwstawne pochodzącemu z tego języka słowu ereb (,zachód”), w którym dopatrują się źródłosłowu nazwy Europa. Co ciekawe, takie samo przeciwstawienie obecne jest również $\mathrm{w}$ akadyjskim (tam termin ten występuje w formie erebu $(m))^{5}$. Ta dialektyka jest zachowana w szczególnie ostrej formie w greckich źródłach historiograficznych. Już pierwsza księga „Dziejów” Herodota sytuuje wojny grecko-perskie w optyce nieprzezwyciężalnych napięć między Wschodem a Zachodem. 'A $\sigma \square \alpha$ to dla Herodota przede wszystkim kontynent ${ }^{6}$, ale dostrzega on wyraźnie odrębność Anatolii, nazywając ją „dolną częścią Azji”7 (termin Asia Minor w znanych nam przekazach piśmienniczych pojawia się dopiero w V stuleciu po Chr. w „Historii” Pawła Orozjusza ${ }^{8}$ ), i odróżniając od „Azji powyżej rzeki Halys”. . Nie do końca natomiast jasne jest, w jakim znaczeniu słowo to użyte jest na przykład we fragmencie, w którym „ojciec historii" wyznaje swą niewiedzę względem tego, czemu wszystkie trzy części świata - Libia, Europa i Azja - biora swą nazwę od imion kobiecych ${ }^{10}$. Jako granicę między Azją a Europą podaje on kolchidzką rzekę Phasis, co wcale nie przybliża nas do rozwiązania zagadki zasięgu terytorialnego Azji tak jak był on ówcześnie postrzegany, gdyż Phasis położona jest na północno-wschodnich obrzeżach Anatolii. Azja to według Herodota imię żony Prometeusza, choć inna wersja mitu mówi, że była ona matką tytana, a żoną Japeta i córką Oke-

${ }^{5}$ DGRG, s.v. Asia.

${ }^{6}$ Zob. np. Hdt. 1,4,1; 1,95,1; 1,95,2; etc.

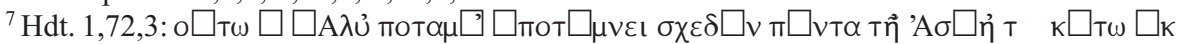

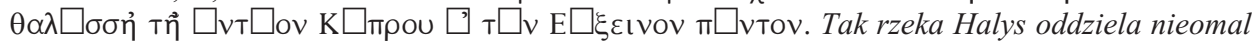
cała dolnq [część] Azji od morza [położonego] naprzeciwko Cypru do Morza Czarnego. Zob. również Hdt. 1,177,1.

${ }^{8}$ CE, t. 1, s.v. Asia Minor.

${ }^{9}$ Hdt. 1,103,2.

${ }^{10}$ Hdt. 4,45,2. 
anosa i Tethys ${ }^{11}$. Dwaj inni wielcy prozaicy - Ksenofont ${ }^{12}$ i będący „pomostem" między Grecją a Rzymem Polibiusz ${ }^{13}$ - podobnie jak Herodot używali tej nazwy intuicyjnie, przypisując jej różne znaczenia. Wydaje się więc, że z początku zachodzące na siebie treści oznaczane przez pojęcie „Azja” dosyć późno zaczęły być rozpoznawane z wystarczającą precyzją.

Po ekspansji rzymskiej na tereny wschodnie kultura grecka zaczyna otwierać sobie na oścież wrota Rzymu, by „ujarzmić dzikiego zwycięzcę"14. Szczególnie dużo pracy na tej niwie wykonują wybitne postaci należące do nieformalnego zrzeszenia wokół rodu Scypionów. Z czasem normą stanie się bilingwizm i naśladowanie greckich wzorców kulturowo-cywilizacyjnych, od najbardziej niewolniczych przekładów i imitacji, aż po tak zwaną aemulatio. Żeby nie szukać zbyt daleko wystarczy nadmienić, że słynny Gaius - jeden z niekwestionowanych bohaterów niniejszej pracy - w swoich dziełach cytuje Solona, Ksenofonta, a nawet Homera ${ }^{15}$. Pomimo popularnego poglądu, że dla Rzymian Azją były jedynie zachodnie wybrzeża Anatolii wraz z terytoriami sąsiednimi, czyli Myzją, Lidią, Karią i Frygią ${ }^{16}$, sytuacja wydaje się dużo bardziej skomplikowana. Niestety nie dysponujemy żadnymi źródłami w postaci map z tamtego okresu. Istnieje co prawda późna, trzynastowieczna kopia rzymskiej mapy turystycznej z IV wieku po Chr. - tak zwana Tabula Peutingeriana $^{17}$, która być może jest oparta na mapie Marka Wipsaniusza Agryppy, przyjaciela i dowódcy floty Oktawiana Augusta, jednak nie jest ona materiałem, z którego można $\mathrm{z}$ racjonalną dozą prawdopodobieństwa wyciagać wnioski związane $\mathrm{z}$ omawianym tu zagadnieniem ${ }^{18}$. Mapa była złożona z dwunastu pergaminowych fragmentów wyobrażających prawie cały znany ówcześnie świat ${ }^{19}$. Dla nas najbardziej interesujące są fragmenty VIII i IX, na których przedstawiona jest Azja Mniejsza. Pomijając ogromną niedokładność źródła,

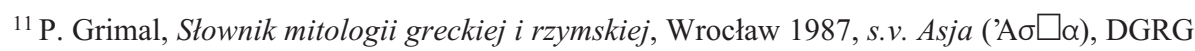
s.v. Asia.

${ }^{12}$ Xen. an. 7,1,1; 7,2,1; 7,2,3 etc.; Xen. hell. (przede wszystkim księga trzecia, która w dużej cześci poświęcona jest omówieniu udziału Persji w wojnach greckich): $3,1,1 ; 3,1,5 ; 3,2,11 ; 3,2,21$; 3,4,2; 3,4,11; 3,5,1; 3,5,5 (Azja wymieniona w opozycji do Grecji); 3,5,13 (Lizander - „król Azji”, na pewno nie może tu więc chodzić o cały kontynent); 4,2,4; 4,2,5; 4,2,6 (wojska mają na życzenie króla Sparty, Agesilaosa, przeprawić się z Azji do Europy); 4,8,21; 5,3,8 etc.

${ }^{13}$ Por. np. Pol. 1,2,1; 1,3,1; 1,3,2. W kontekście Polibiusza fakt ten musi być szczególnie wyraźnie podkreślony, biorąc pod uwagę ogromny wpływ, jaki wywarł on na opus vitae Liwiusza.

${ }^{14}$ Hor. epist. 2,1,156.

${ }^{15}$ J. Ledlie, Gaius, 13 „Journal of the Society of Comparative Legislation” 2 (1913), s. 235.

${ }^{16}$ Por. CE, t. 1, s.v. Asia Minor. W takim znaczeniu używa go między innymi Plaut (Plaut. Stich. $2,2,95 ; 2,2,43)$.

${ }^{17}$ Nazwa jej pochodzi od niemieckiego antykwariusza i wydawcy szesnastowiecznego - Konrada Peutingera.

${ }^{18}$ Zdjęcia mapy, a także uwagi dotyczące zaznaczonych na niej lokalizacji, dostępne są na stronie http://www.euratlas.net/cartogra/peutinger/index.html (20 grudnia 2011).

${ }^{19} \mathrm{Na}$ początku było ich dwanaście, zaginął jednak arkusz przedstawiający Półwysep Iberyjski. 
można chyba stwierdzić, że Azja rozumiana jest tam w sposób bardzo zawężony - jako politycznie wyodrębniona prowincja rzymska. Nie jest to oczywiście żadnym zaskoczeniem i widać jasno, że w badaniu tego problemu należy wziąć pod uwagę przede wszystkim źródła pisane. W czasach rzymskich istnieją bowiem aż trzy główne desygnaty nazwy „Azja”: Azja - wielki kontynent na wschodzie, Azja Mniejsza i provincia Asia ${ }^{20}$. Różnic tych świadomi są twórcy rzymscy. Jako pierwszy nową, zupełnie odrębną kategorię wprowadza żyjący na przełomie er Strabon w „Geografii”, ujmując zagadnienie w słowach:

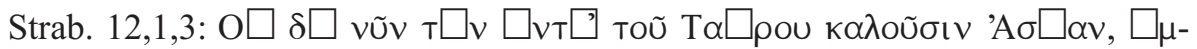

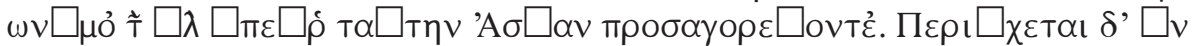

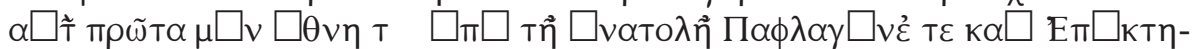

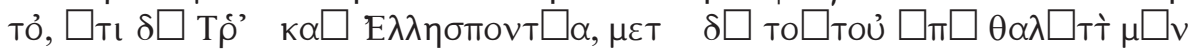

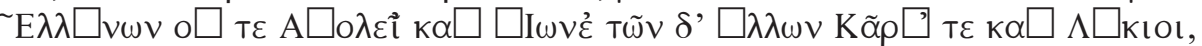
$\square v \delta \square \stackrel{\top}{\mu} \mu \varepsilon \sigma o \gamma \alpha \square \Lambda \cup \delta \circ \square$.

Współcześni nazywają Azją [obszar] po tej stronie Taurusu, czerpiąc tę nazwę od imienia całego kontynentu. Obejmuje ona pierwsze ludy na wschodzie: Paflagonów, Frygów i Lykaonów, następnie Bitynów, Myzów i Epiktetos, Troadę i Hellespont, a za nimi spośród Hellenów [zamieszkałych] przy morzu Eolów, Jonów, a z innych także Karów i Lików, a również [położonych] w głębi lądu Lidów.

Geograf wspomina zarazem, że nie on jest autorem nowego zastosowania tej nazwy, lecz używana jest ona przez ludzi żyjących w jego czasach. Nie do końca jednak jest jasne, jak rozumieć mamy wyrażenie o $\square \delta \square$ vũv - czy chodzi tu o pisarzy, na których Strabon się powołuje ${ }^{21}$, czy o popularne użycie tej nazwy wśród ludzi z jego otoczenia. Victor Chapot twierdzi, że są to terytoria z przewagą albo z dużym udziałem żywiołu greckiego ${ }^{22}$, zaś reszta Azji mniejszej według Strabona nie leży w zakresie tego pojęcia. Jest to dla francuskiego historyka prawa świadectwo ówczesnej integracji Greków wokół idei etnicznych ${ }^{23}$. Podaje on także przykłady specyficznego precyzowania nazwy Azja w czasach rzymskich, gdy mowa jest wyłącznie o prowincji: $\square \mu \phi \square$

${ }^{20}$ Jednak posiadłości terytorialne tej prowincji na terenie Anatolii zmieniały się przez kilka wieków jej istnienia. Zob. V. Chapot, La province Romaine proconsulaire d'Asie depuis ses origines jusqu'à la fin du Haut-Empire, Paris 1904, s. 80 nn.

${ }^{21}$ Tak m.in. w angielskim tłumaczeniu H. Jones (ed.), The Geography of Strabo, London 1924.

${ }^{22}$ Mogłoby to korespondować z przekazem Ksenofonta, który w wielu miejscach, gdzie mówi o Azji, wspomina Greków tam żyjących. Zob. Xen. hell. 3,1,3; 3,2,11; 3,2,12; 3,4,5; 3,4,25; 4,8,27.

${ }^{23}$ V. Chapot, La province..., s. 71.

${ }^{24}$ Np. App. civ. 5,1,4.

${ }^{25}$ App. civ. 3,1,2.

${ }^{26}$ Azja wokół/przy Pergamonie, Azja przy Jonii, tak zwana Azja. 


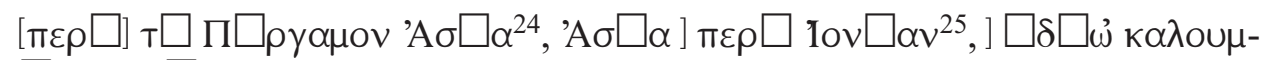
$\square \vee \eta$ 'A $\square \alpha^{26}$, a następnie podział Warrona:

Varro ling. 5,3: Ut Asia sic caelum dicitur modis duobus. Nam et Asia, quae non Europa, in quo etiam Syria, et Asia dicitur prioris pars Asiae, in qua est Ionia ac provincia nostra ${ }^{27}$.

O Azji, tak jak i o niebie, mówi się na dwa sposoby. Bo Azjąjest to, co nie jest Europą, a gdzie znajduje się także Syria; Azją zwie się także pierwsza część Azji, do której należy Jonia i nasza prowincja.

V. Chapot uważa, że Azja prokonsularna obejmowała anatolijskie terytoria zhellenizowane, w naturalny sposób ciążące ku Zachodowi, z wyłączeniem jednak terytoriów położonych nad Morzem Czarnym - przede wszystkim Bitynii, która z początku też ukształtowana została jako prowincja senatorska oraz wybrzeży południowej Azji mniejszejej.

W tym miejscu można się zastanowić, które z powyższych znaczeń warunku mogło wywrzeć największy wpływ na umysłowość autora posługującego się nim w swym tekście po raz pierwszy, aby następnie ustalić, czy czerpiący z jego dorobku wykazywali jakąś pogłębioną refleksję nad jego użyciem. Pierwsze znane nam teksty prawne zawierające zwrot si navis ex Asia venerit pochodzą z II wieku po Chr., a więc czasów, kiedy w świadomości ludzkiej funkcjonowały w sposób zogniskowany przedstawiane wcześniej niejednolite znaczenia terminu „Azja”. Jest to czas najbujniejszego rozkwitu imperium, a równocześnie okres, w którym dająjuż o sobie znać niektóre symptomy jego upadku $^{29}$. Nieświadome jednak swego przesądzonego losu, niemal wszystkie części cesarstwa przeżywały gwałtowny wzrost gospodarczy. Azja była najbardziej zurbanizowaną prowincją, miało tam bowiem znajdować się nawet około pięciuset miast, dziesiątki portów, spośród których wiele było świadkami jeszcze czasów hellenistycznych, klasycznych ${ }^{30} \mathrm{i}$ wcześniejszych ${ }^{31}$. Tradycyjnie potężnymi ośrodkami były miasta przybrzeżne, między innymi Efez, Milet, Priene, Halikarnas, Smyrna i Pergamon. Wiele z miast azjatyckich było głównymi centrami rzemieślniczymi Wschodu, mającymi również świetnie funkcjonujące instytucje municypalne, których istnienie na ogół szanowali rzymscy zdobywcy. Dodatkowo, zachodnie wybrzeże Anatolii miało jedną z najlepiej wykształconych linii brzegowych, co w oczywisty sposób sprzyjało handlowi morskiemu i rozwojowi portów. Choć inne prowincje również się

${ }^{27}$ Przykłady powyższe podane są na s. 70-71, w rozdziale III pt. Le territoire de la province ses limites.

${ }^{28}$ V. Chapot, La province..., s. 87.

${ }^{29} \mathrm{Na}$ przykład psucie monety.

${ }^{30}$ Tzn. V w. przed Chr.

${ }^{31}$ Por. DGRG, s.v. Asia; M. Jaczynowska, Historia starożytnego Rzymu, Warszawa 1983, s. 273 in fine. 
bogaciły - to właśnie Azja była nieomalże synonimem dostatku i spokoju. Już sam fakt, że była ona prowincją senacką świadczył dobitnie o sytuacji tam panującej, gdyż w prowincjach takich nie stacjonowały legiony ${ }^{32}$. Niektóre zaś $\mathrm{z}$ prowincji leżących w Azji rozumianej jako kontynent znajdowały się pod rządami namiestników cesarskich i były tam rozmieszczone liczne wojska. Należy jednak pamiętać, że navis niekoniecznie musi oznaczać okręt handlowy (navis mercatoria). Z Syrii, Judei czy innych terenów leżących poza granicami wydzielonej administracyjnie prowincji Azji mogły bowiem pływać wspominane m.in. przez Cezara i Liwiusza naves longae albo inne statki przewożące ludzi niekoniecznie podróżujących z zamiarem handlowania. Warto tu wspomnieć chociażby o turystach lub pielgrzymach ${ }^{33}$ - choć druga $z$ tych kategorii w kontekście umysłowości jurysty rzymskiego z II wieku ma raczej niewielką rację bytu ${ }^{34}$. Wydaje się jednak, że ktokolwiek pierwszy zastosował w swych pismach prawniczych warunek si navis ex Asia venerit, musiał myśleć przede wszystkim o statku handlowym. Nie bez przyczyny chyba teksty te pojawiają się w czasie, gdy Rzym przeżywa swój największy wzrost ekonomiczny i cieszy się wieloletnim już pokojem sprzyjającym rozkwitowi gospodarki.

Pod kątem niniejszej pracy niezwykle znamienne jest to, że istotnym miernikiem tego wzrostu są wyniki badań nad wrakami statków handlowych odkrywanymi ciągle w wodach Morza Śródziemnego ${ }^{35}$, choć nawet zwolennicy ich wiarygodności wyrażają wątpliwości co do obrazu stosunków ekonomicznych przez nie odzwierciedlanych ${ }^{36}$. W szczególności czynnikiem mogącym zafałszować ten obraz jest fakt, że archeologowie mają bardzo okrojone dane dotyczące statków przewożących wszystkie te rodzaje produktów handlowych,

${ }^{32}$ Wyjątkiem była Afryka, w której przebywała legio III Augusta. Ostatecznie przeniesiono jednak jej obóz do utworzonej pod koniec II w. po Chr. prowincji Numidii. M. Jaczynowska, Historia ..., s. 215 .

${ }^{33}$ Zob. np. G. Williamson, Mucianus and a Touch of the Miraculous. Pilgrimage and Tourism in Roman Asia Minor, [w:] J. Elsner, I. Rutherford (eds), Pilgrimage in Graeco-Roman and Early Christian Antiquity. Seeing the Gods, Oxford 2005, s. 219-252.

${ }^{34}$ Dominujące w nauce są opinie o wzroście wolumenu migracji za pryncypatu, do czego przyczynił się długotrwały okres pokoju. Różne grupy ludzi podróżujących na terenach wschodnich imperium wymienia Susan Alcock, The Eastern Mediterranean, [w:] W. Scheidel, I. Morris, R. Saller (eds), The Cambridge Economic History of the Greco-Roman World, Cambridge 2007, s. 691. Plaut w swoich komediach wymienia bardzo różne rodzaje statków. Najczęściej oczywiście używa samego słowa navis, jednak natykamy się między innymi na: navis mercatoria (Plaut. Bacch. 2,3,2), navis oneraria (Plaut. Poen. 3,3,37), navis cercurus (Plaut. Merc. 1,1,86) celox (Plaut. Cap. 4,2,94), lembus (Plaut. Bacch. 2,3,45; 2,3,71 i in.) etc. [za:] C. Knapp, Travel in Ancient Times as Seen in Plautus and Terence. II, 2 „Classical Philology” 3 (1907), s. 281-304.

${ }^{35}$ Wszystkie dane, którymi posługuję się w związku z tematem badań wraków, pochodzą z opublikowanej niedawno pracy, A. Wilson, Approaches to Quantifying Roman Trade, [w:] A. Bowman, A. Wilson (eds), Quantifying the Roman Economy. Methods and Problems, Oxford 2009, s. 213-249, zwł. rozdz. Shipwrecks (s. 219-229) i cytowana tam literatura, w szczególności opracowania A. Parkera, na których Wilson w znacznej części bazował.

${ }^{36}$ A. Wilson, Approaches... (Shipwrecks), passim; S. Alcock, The Eastern..., s. 673, 690. 
których ciężar nie jest w stanie zapobiec rozpadowi kadłuba. Dotyczy to przede wszystkim tak ważnych artykułów spożywczych, jak zboże (ta okoliczność utrudnia dokładne oszacowanie importu ze znanej z jego produkcji prowincji Afryki) lub wino. Liczba odkryć mniejsza jest zwłaszcza dla okresu, w którym w większym użyciu znalazły się beczki. Wcześniej bowiem wino i inne produkty, takie jak oliwa, ryby, orzechy, smoła, owoce, a czasem także zboże, były przewożone $\mathrm{w}$ amforach ${ }^{37}$. Najwięcej ze znanych archeologom statków było załadowanych amforami lub marmurem ${ }^{38}$, dlatego też nie zawsze możemy dokładnie orzec, czy mniejsza liczba wraków pochodzących z II-VII wieku po Chr. świadczy o załamaniu handlu w ogóle, czy może w pewnym zakresie jest wytłumaczalna zmianą sposobu przewożenia niektórych artykułów spożywczych z amforowego na beczkowy ${ }^{39}$. Dodatkowe utrudnienia w klasyfikacji naukowej znalezisk archeologicznych w postaci wraków statków śródziemnomorskich powodują między innymi: niezgodność danych z innymi źródłami (również niearcheologicznymi) ${ }^{40}$, niejednolite postępy badań w różnych częściach dawnego cesarstwa ${ }^{41}$ oraz różne metody periodyzacji, które często prowadzą do rozbieżnych interpretacji znalezisk ${ }^{42}$. Nie do końca sprawdzone jest także założenie jednolitego prawdopodobieństwa katastrofy morskiej w różnych okresach, nieuwzględniające postępu technologicznego w czasach rzymskich ${ }^{43}$, a także trudna dostępność dla płetwonurków pewnych obszarów morskich, gdzie można by się spodziewać odkrycia wraków statków o zdecydowanie większej ładowności ${ }^{44}$. Niezależnie jednak od wszystkich tych zastrzeżeń należy stwierdzić, że praca archeologów pozwala uprawdopodobnić tezę o sformułowaniu warunku si navis ex Asia venerit pod niewattpliwie dojmującym wpływem coraz bogatszego rozwoju handlu morskiego w okresie wczesnego cesarstwa $^{45}$. W II wieku po Chr. następuje bowiem schyłek kilkusetletniego

${ }^{37}$ A. Wilson, Approaches... (Amphorae), s. 229. Statki przewożące zboże znajdujące się w amforach są dla archeologów zdecydowanie częstszym znaleziskiem niż te, które przewoziły je w workach.

${ }^{38}$ A. Wilson, Approaches... (Shipwrecks), s. 219.

${ }^{39}$ Ibidem, s. 220-221, 224 in fine, 226.

${ }^{40}$ Ibidem, s. 221.

${ }^{41}$ Ibidem, s. 221-222, 226. Chodzi tu przede wszystkim o mało zbadane wybrzeże afrykańskie na całej niemal jego długości.

${ }^{42}$ Ibidem, s. 222-226.

${ }^{43}$ Ibidem, s. 228-229.

${ }^{44}$ Ibidem, s. 229.

${ }^{45}$ Niebagatelne znaczenie miał tu również handel niewolnikami. Susan Alcock w mającym pewne znaczenie dla niniejszej pracy fragmencie pisze: Thrace, western Asia Minor, Syria and - at times - Judaea were known surplus producers of slaves. Various eastern cities, most famously Ephesus, served as large-scale collection and distribution centers. The chiefflow of bodies, no doubt, was towards Italy, but a degree of local and regional consumption must also be assumed. S. Alcock, The Eastern..., s. 690.

${ }^{46}$ A. Wilson, Approaches... (Shipwrecks), zwł. tabele na s. 220, 223 i 225.

${ }^{47}$ Ibidem, s. 227-229; E. Lo Cascio, The Early Roman Empire: The State and the Economy, [w:] W. Scheidel, I. Morris, R. Saller (eds), The Cambridge ..., s. 640-641. 
okresu największej intensyfikacji handlu tego rodzaju ${ }^{46}$, także pod względem tonażu statków przewożących towary ${ }^{47}$. Nawet gdyby przyjąć jego chwilowe załamanie się w okresie powstawania pierwszych tekstów jurystów zawierających warunek ${ }^{48}$, nie mogło to mieć wpływu na wyparcie tego istotnego czynnika rozwoju z ich świadomości.

Kończąc niniejszy fragment rozważań, należy przedstawić dużo bardziej adekwatny argument przemawiający za tym, że jurysta, który wprowadził do swego tekstu słowa si navis ex Asia venerit, miał na myśli przede wszystkim zachodnie wybrzeże rzymskiej prowincji. Wysublimowany umysł jurysty był bardziej skłonny do posługiwania się terminis technicis i słowami jak najbardziej precyzyjnymi, powstającymi nieraz przy użyciu dialektyki, mającymi ograniczony zakres desygnatów, a za to niosącymi za sobą więcej informacji, np. fundus Tusculanus, vini Campani optimi amphorae centum etc. ${ }^{49} \mathrm{~W}$ szczególności dwa poniższe fragmenty, dotyczące dystynkcji pomiędzy prowincjami w pismach rzymskich prawników, powinny rozwiać watpliwości dotyczące operowania przez nich nazwami poszczególnych terytoriów.

D. 40,2,5 (Julian ks. 42 digestorum): An apud se manumittere possit is qui consilium praebeat, saepe quaesitum est. Ego, qui meminissem Iavolenum praeceptorem meum et in Africa et in Syria servos suos manumisisse, cum consilium praeberet, exemplum eius secutus et in praetura et consulatu meo quosdam ex servis meis vindicta liberavi et quibusdam praetoribus consulentibus me idem suasi.

Często pytano o to, czy może sam wyzwolić niewolnika ten, który odbywa consilium. Ja, który pamiętam mego nauczyciela Jawolena, jak wyzwalał swoich niewolników w Afryce i w Syrii, gdy odbywał consilium, podążywszy za jego przykładem podczas pretury i mego konsulatu wyzwalałem niektórych z moich sług za pomocą vindicta. I doradzałem czynić to samo niektórym, pytającym mnie o to pretorom.

Tekst wyraźnie wymienia w jednym szeregu Afrykę i Syrię. Trudno byłoby się spodziewać, że przy takim ułożeniu wypowiedzi jurysta tylko w drugim przypadku ma na myśli prowincję, a mówiąc „Afryka”, myśli o całym południowym wybrzeżu Morza Śródziemnego i o wszystkich przylegających doń prowincjach. Oczywiście taka interpretacja nie wykraczałaby jednak poza możliwy horyzont znaczeniowy tej wypowiedzi. Przytoczmy więc jeszcze jeden fragment, który kontrast ten przedstawia w jeszcze bardziej jaskrawy sposób:

\footnotetext{
${ }^{48} \mathrm{Na}$ co wskazują niektóre wyniki badań wraków.

${ }^{49}$ Zob. np. D. 45,1,74. Oczywiście nie jest to zawsze przestrzegana prawidłowość, ale na pewno widać dążenie jurystów w tym kierunku.
} 
D. 34,1,14,3 (Ulpian ks. 2 fideicommissorum): Quidam libertis suis ut alimenta, ita aquam quoque per fideicommissum reliquerat: consulebar de fideicommisso. Cum in ea regione Africae vel forte Aegypti res agi proponebatur, ubi aqua venalis est (...)

Pewien człowiek zostawił swoim wyzwoleńcom w fideikomisie żywność i wodę. Zostałem zapytany w kwestii fideikomisu. Jako że sprawie nadano bieg w tym regionie Afryki, czy może bardziej Egiptu, gdzie woda jest na $\operatorname{sprzedaż~}^{50}(\ldots)$

Wydaje się, że autor myślał o relacji zakresowej między desygnatami pojęć „Afryka” i „Egipt” jako o relacji wykluczania. Za pomocą spójnika vel można bowiem w łacinie oprócz alternatywy zwykłej wyrażać również alternatywę rozłączną ${ }^{51}$. Gdyby zamiast formy dopełniaczowej Aegypti rzeczownik Aegyptus pojawił się w narzędniku - wtedy sytuacja byłaby zgoła inna. Nawet gdyby jednak przyjąć, że Afryka ${ }^{52}$ jest tu rozumiana szeroko, a nie jako prowincja, jurysta sam siebie koryguje, by wybrać bardziej precyzyjne sformułowanie.

Ostatnia uwaga wiąże się z postacią słynnego Gaiusa. Gdyby okazało się, że nie był on pierwszą osobą, która posłużyła się słowami si navis ex Asia venerit, i tak wszystko wskazuje na to, że przejawiał on dużą elastyczność i dostosowywał swoje teksty do warunków, w jakich przyszło mu żyć53. Podsumowując, należy stwierdzić, że autor warunku si navis ex Asia venerit miał na myśli przede wszystkim statek handlowy płynący do Rzymu z któregoś z portów Azji prokonsularnej, a biorąc pod uwagę zainteresowania wielu jurystów - być może był to statek pełen niewolników płynący z Efezu, stolicy prowincji. To ostatnie stwierdzenie jest już jednak czystą spekulacją.

II. Chronologia tekstów. Zachowane fragmenty pism rzymskich jurystów zawierające słowa interesującego nas warunku być może w niewielkim tylko stopniu oddają częstotliwość jego użycia. W szczególności nie odnajdujemy ani jednego takiego przykładu u veteres ${ }^{54}$. Bardzo ciężko stwierdzić, czy powodem tego jest fakt, że w ogóle został on wprowadzony do piśmiennictwa prawniczego dopiero na przełomie I i II wieku po Chr., czy po prostu funkcjo-

\footnotetext{
${ }^{50}$ Venalis thumaczę w znaczeniu orzecznikowym, a nie przydawkowym.

${ }^{51}$ Zob. np. C. Lewis, C. Short, A Latin Dictionary, Oxford 1879, s.v. vel.

${ }^{52}$ Prima facie można powiedzieć, że problem z odróżnieniem Afryki - kontynentu i Afryki prowincji może być analogiczny do problemu „azjatyckiego”. Gaius nie pierwszy raz zrobił więc dowcip tym, którzy próbują rozszyfrować zagadki związane z jego pismami, gdyż pojawia się tam zarówno warunek si navis ex Asia venerit, jak i si navis ex Africa venerit.

${ }^{53}$ Zob. infra, w szczególności rozważania dotyczące Gaiusa jako potencjalnego autora warunku, a także słów si navis ex Africa venerit.

${ }^{54}$ Zarówno republikańskich, jak i wczesnoklasycznych. Co do zakresu terminu por. np. W. Litewski, Jurysprudencja..., s. 19; M. Sobczyk, Pojęcie 'causa' w źródłach prawa rzymskiego odnoszacych się do bezpodstawnego wzbogacenia, 11 Zeszyty Prawnicze UKSW 1 (2011), s. 273 i lit. cytowana w przyp. 16.
} 
nował wcześniej w jednym lub kilku dziełach, które nie przetrwały do naszych czasów. W szczególności nie dotarło do nas poprzez tradycję bezpośrednią nic z wczesnej republiki, a z czasów późnorepublikańskich ostały się głównie wyjątki z zakresu prawa publicznego i sakralnego ${ }^{55}$. A przecież już świadectwa literackie o trzy wieki wcześniejsze wydają się wskazywać na duże prawdopodobieństwo zapożyczenia z tekstów nieprawniczych ${ }^{56}$. W „Stichusie”, jednej z komedii Plauta tworzącego na przełomie III i II wieku przed Chrystusem, spotykamy się ze swojsko brzmiącymi fragmentami:

Plaut. Stich. 1,2,94-1,2,95: nam illum ecastor mittere ad portum volo si quae forte ex Asia navis heri aut hodie venerit.

Bo chcę go, na Kastora, wysłać do portu, żeby [sprawdził] czy przypadkiem wczoraj albo dziś jakiś statek nie przypłynął z Azji.

oraz

Plaut. Stich. 2,2,42-2,2,44: dum percontor portitores, ecquae navis venerit ex Asia, negant venisse, conspicatus sum interim cercurum, quo ego me maiorem non vidisse censeo.

Kiedy pytałem urzędników portowych, czy statek przypłynął z Azji, a [oni] odpowiadali, że nie, zobaczyłem w międzyczasie żaglowiec, od którego większego sądzę, że nigdy nie widziałem ${ }^{57}$.

W innym utworze, zatytułowanym Truculentus, jeden z bohaterów Charmides - również wraca z Azji. Należy oczywiście pamiętać, że akcja palliaty ma miejsce na lądzie greckim, stąd też podróże do Azji były w tamtych realiach czymś zdecydowanie bardziej oczywistym niż jeszcze w Rzymie za czasów Plauta. Nie można przy tym wyliczeniu pominąć oczywiście opus magnum słynnego komediopisarza, „Żołnierza Samochwała”. Pasożyt Artotrogus przypomina tam głównemu bohaterowi, jak wielką liczbą zabitych wrogów się on chełpił. Podobno pozbawiał ich życia między innymi w takich rejonach Azji jak Cylicja, Sardes i Kapadocja, a sam król Seleukos miał go prosić, aby zwerbował mu żołnierzy ${ }^{58}$.

${ }^{55}$ W. Litewski, Jurysprudencja ..., s. 59.

${ }^{56}$ Tym bardziej że w okresie wczesnej republiki frazeologia prawnicza pełnymi garściami czerpała ze sformułowań używanych powszechnie. O tym w kontekście terminorum technicorum W. Litewski, Jurysprudencja ..., s. 92, w kontekście ogólnym - s. 91.

${ }^{57} \mathrm{~W}$ obydwu tekstach czasownik venerit użyty jest nie w czasie futurum exactum, lecz w trybie coniunctivus perfecti $\mathrm{w}$ funkcji gramatycznej coniunctivi obliqui.

${ }^{58}$ Plaut. Mil. 1,1,42-1,1,54. 
W dostępnych nam tekstach słowami si navis ex Asia venerit posługiwali się następujący juryści (podaję nazwiska i sigla według częstotliwości występowania w zachowanych fragmentach):

Ulpian sześć razy (D. 4,8,11,5; D. 26,2,8,3; D. 35,1,2; D. 35,1,10,1; D. $37,11,2,1$; D. $46,7,13 \mathrm{pr}$.);

Paulus cztery razy (D. 12,6,60pr.; D. 18,6,8,1; D. 33,2,21; D. 44,7,44,2);

Africanus trzy razy (D. 21,2,46,2; D. 23,4,23; D. 45,1,63);

Julian dwa razy (D. 35,1,21; D. 37,11,8pr.);

Gajus dwa razy (D. 28,5,33; D. 46,1,72);

Celsus (D. 28,5,60,6) i Pomponiusz (D. 32,54) tylko raz.

Oprócz tego Fragmenta Vaticana przekazująjeden wyjątek z pism Paulusa (FV. 50), a „Instytucje” justyniańskie (I. 3,19,14) - pismo niezidentyfikowanego jurysty (być może Gaiusa). Jak więc widać, warunku si navis... użyło aż trzech z pięciu jurystów wymienionych w słynnej konstytucji raweńskiej z 426 roku, a oprócz nich tak wybitne autorytety prawnicze jak Celsus i Julian.

W świetle tych tekstów chronologicznie więc pierwszym, który mógł użyć tego wyrażenia, jest Publius Iuventius Celsus (syn), Julian, Gaius albo Pomponiusz. Oczywiście milcząco zakładamy, że nie posłużył się nim wcześniej jakiś inny jurysta, którego dzieło zaginęło. Za autorstwem Celsusa przemawiałaby jego oryginalność, czasami nawet przechodząca w szyderstwa i uszczypliwości ${ }^{59}$, zdolność do tworzenia bon motów oraz ujmowania zagadnień bardzo trafnie dobranymi, lapidarnymi i zapadającymi w pamięć słowami, a także ogromna jak na reprezentanta swojej grupy zawodowej pomysłowość i barwność języka. Wydaje się także, że Julian jako autor warunku jest mało prawdopodobny - wiele przemawia bowiem za tym, iż obydwaj juryści za sobą nie przepadali. Mimo to Celsus jest cytowany przez Juliana ${ }^{60}$ (D. 28,2,13pr.), podczas gdy odwrotna sytuacja w zachowanych tekstach nie ma miejsca ani razu ${ }^{61}$. Co prawda, Celsus mógłby zacytować ten warunek za pośrednictwem Gajusa, do końca nie wiadomo jednak, który z dwóch prawników (mam na myśli Gajusa i Juliana) zaczerpnął treść tego warunku od drugiego ${ }^{62}$. Dzieła ich były bowiem publikowane mniej więcej w tym samym czasie i obydwaj wzajemnie się

${ }^{59}$ Por. D. 28,1,27 (Celsus ks. 15 digestorum): Domitius Labeo Celso suo salutem. Quaero, an testimonium numero habendus sit is, qui, cum rogatus est ad testamentum scribendum, idem quoque cum tabulas scripsisset, signaverit. Iuventius Celsus Labeoni suo salutem. Non intellego quid sit, de quo me consuleris, aut valide stulta est consultatio tua: plus enim quam ridiculum est dubitare, an aliquis iure testis adhibitus sit, quoniam idem et tabulas testamenti scripserit. (wyróżnienie J. O.)

${ }^{60}$ O. Lenel, Palingenesia iuris civilis, Lipsiae 1889, t. 1, szp. 145, Iulianus nr 115.

${ }^{61}$ W. Litewski, Jurysprudencja ..., s. 139.

${ }^{62}$ Co do kontrowersji przy datowaniu relacji chronologicznych dzieł Juliana, Gajusa i Pomponiusza, zob. A.M. Honoré, Gaius, s. 46-69. Jego zdaniem, Julian był prawdopodobnie najstarszy, jednak, jak słusznie zauważa autor, samo w sobie nie powinno to być przesłanką do ustalania kolejności, w jakiej powstawały ich prace. 
cytują. Jako że Gaius zawarł ten warunek już w księdze drugiej komentarza do edyktu pretora miejskiego, a Julian dopiero w księgach dwudziestej czwartej i trzydziestej pierwszej „Digestów”, być może to Gaius użył warunku przed Julianem $^{63}$. Pomponiusz jako autor warunku jest chyba najmniej prawdopodobny, ponieważ zaczął on tworzyć swój „Komentarz do Sabinusa” mniej więcej w tym samym czasie co Gaius Ad edictum praetoris urbani, a Gaius musiałby zacytować go co najwyżej poprzez Juliana, ponieważ Julian był jedynym ze współczesnych mu jurystów, których cytował autor „Instytucji” ${ }^{64}$. Tezę powyższą potwierdza fakt, że Pomponiusz był chyba najbardziej wtórnym z czterech omawianych jurystów. Za tym, że Celsus użył warunku wcześniej niż Julian, przemawia moim zdaniem również to, iż jedyny znany nam przypadek użycia si navis... przez Celsusa zawarty jest w szesnastej księdze jego „Digestów”, a z księgi piętnastej pochodzi wymieniony wcześniej wyjątkowy cytat z Celsusa autorstwa Juliana ${ }^{65}$. Jest to dosyć zastanawiające sąsiedztwo, które uprawdopodabniać może fakt pierwszeństwa Celsusa w stosunku do drugiego z jurystów. Raczej nieodpowiednią metodą będzie ustalanie chronologii na podstawie częstotliwości użycia si navis... Po pierwsze - Palingenesia wskazuje rozmiar przypuszczalnych spustoszeń dokonanych w dziełach Celsusa ${ }^{66}$, po drugie - można przedstawić w tym względzie zupełnie kontradyktoryjne argumenty. Jedni mogą powiedzieć, że jednokrotne użycie potwierdza jego autorstwo, gdyż, uczynione mimochodem, mogło przypaść do gustu innemu juryście, który zwielokrotnił pojawianie się tych słów, inni - że Celsus musiałby zastosować je więcej razy, aby przemówiły do świadomości jego następców, którzy dopiero tym sposobem mogli je podchwycić. Przesłanki, na których opierają się niniejsze rozważania, i tak nie są zbyt pewne, nie będę się więc starał czynić ich jeszcze bardziej wątpliwymi.

Pozostaje nam jeszcze rozstrzygnąć kwestię relacji chronologicznej Celsusa do Gaiusa. Obydwaj byli bardzo innowatorskimi jurystami, wprowadzenie nowego warunku pasowałoby więc do „profilu psychologicznego" każdego $\mathrm{z}$ nich. O ile więc nie zostaliśmy wpędzeni zupełnie w ślepą uliczkę - a stałoby się tak, gdyby był to zwrot bardzo popularny w tamtym okresie, pochodzący nie wiadomo od kogo i używany zupełnie intuicyjnie i bez zastanowienia - można w świetle tego, co zostało dotychczas powiedziane, pokusić się o stwierdzenie, że pierwszym, który w swoich pismach użył warunku si

${ }^{63}$ Por. chronologię powstawania kolejnych dzieł Juliana, Gaiusa i Pomponiusza. A.M. Honoré, Gaius, s. 69. Nie zmienia to faktu, że obydwaj juryści mogli dokonywać zmian redakcyjnych w poszczególnych księgach już po ukończeniu całości dzieła.

${ }^{64}$ A.M. Honoré, Gaius, s. 71 in fine: he [scil. Gaius] does not cite contemporary jurists, with the exception of Julian, at all copiously.

${ }^{65} \mathrm{~W}$ Palingenesji sąsiedztwo to jest bardzo dobrze widoczne - obydwa cytaty oddzielają tylko dwie szpalty.

${ }^{66}$ O. Lenel, Palingenesia ..., t. 1, szp. 127-170. 
navis ex Asia venerit, był Celsus albo Gaius. Rzecz w tym, że Gaius raczej na pewno nie cytował Celsusa, a do czasu wydania wzmiankowanej ustawy o cytowaniu, zwanej konstytucją raweńską, jedynym prawniczym świadectwem stwierdzającym realność postaci Gaiusa była niepewna wzmianka u Pomponiusza (D. 45,3,39) ${ }^{67}$. Tony Honoré twierdzi, że Gaius i Pomponiusz mogli być znajomymi i dzielić wspólne zainteresowanie historią prawa ${ }^{68}$. Można więc ustalić następującą chronologię tekstów. Pierwszy warunku użył Gaius, a następnie Pomponiusz ${ }^{69}$, Celsus i Julian ${ }^{70}$. Problem polega na tym, że Celsus nie cytuje Pomponiusza, a Pomponiusz cytuje Celsusa już w księdze trzeciej $A d$ Sabinum (pamiętajmy, że warunek si navis ... występuje u Pomponiusza dopiero w księdze siódmej). Można byłoby rozwiązać ten problem poprzez próbę udowodnienia bezpośredniego cytatu Celsusa z Gaiusa, ale byłby to dopiero drugi znany przypadek cytatu z Gaiusa przed wydaniem konstytucji raweńskiej. Dlatego proponuję hipotezę, że słowa si navis ex Asia venerit zostały użyte przez któregoś z jurystów pierwszego wieku - być może któregoś spośród uczniów Labeona. To wyjaśniałoby, dlaczego mimo braku odniesień do Gaiusa, którego teksty według moich ustaleń jako pierwsze spośród nam znanych zawarły treść tego warunku, nastąpiło szerokie rozpowszechnienie tych słów wśród jurystów. Raczej byłby to jurysta ze szkoły Prokulianów, bo oni byli bardziej niechętni cytowaniu swoich sabiniańskich oponentów, więc większe jest prawdopodobieństwo, że to oni zostaliby zacytowani przez Sabinianów (Gaius, Julian) niż na odwrót (np. Celsus). Za panowania cesarza Hadriana istnienie szkół miało się już ku końcowi ${ }^{71}$, zaś Gaius jest ostatnim spośród wielkich jurystów, u których pojawia się taka polaryzacja stanowisk obydwu szkół, która w tym czasie była już sprawą przebrzmiałą w stolicy ${ }^{72}$. Gaius uznaje się za Sabinianina (nostrae scholae praeceptores...), choć nie podąża za koryfeuszami swojej szkoły bezrefleksyjnie ${ }^{73}$. Sabinianinem jest również

\section{${ }^{67}$ A.M. Honoré, Gaius, s. xi.}

${ }^{68}$ Ibidem, s. 11, 55.

${ }^{69}$ Pomimo to, że „dwa cytowania przez Pomponiusza „Digestów” Juliana wydają się jasno ustalone [D. 15,3,1,2 i D. 39,2,18,5 - przypis A. Honoré] (...). Jest również kilka innych możliwych cytatów Pomponiusza z Juliana i żadnego Juliana z Pomponiusza”. A.M. Honoré, Gaius, s. 57 (tłum. J. O.).

${ }^{70}$ Africanus należy już do następnego pokolenia jurystów, gdyż był uczniem Juliana (zob. W. Litewski, Jurysprudencja..., s. 136), i to „szczególnie niewolniczym” [particularly slavish]. A.M. Honoré, Gaius, s. xv. Mimo to utarło się powiedzenie Africani lex, ergo difficilis (J. Ledlie, The Great ..., s. 244; W. Litewski, Jurysprudencja ..., s. 136), lecz niektórzy zrzucają to na karb interpolacji poklasycznych (W. Litewski, Jurysprudencja ..., s. 136). Problemem z ustaleniem jednoznacznej chronologii między Gajusem a Julianem jest to, że Julian jest cytowany przez Gaiusa aż dwadzieścia pięć razy w samych komentarzach do edyktów. A.M. Honoré, Gaius, s. 30-31.

${ }^{71}$ W. Litewski, Jurysprudencja..., s. 22.

${ }^{72}$ J. Ledlie, The Great..., s. 236.

${ }^{73}$ It is hard to resist the conclusion that his loyalty is deeper and more complex than that of a mere student. A.M. Honoré, Gaius, s. 33. 
Salwiusz Julian, autor Edictum perpetuum, i jego uczeń Africanus. Jednak warunku si navis... używał również Prokulianin Celsus i Pomponiusz, który w ciągu swojego życia zmienił swą przynależność - z Prokulianinia stał się Sabinianinem. Także w okresie panowania dynastii Sewerów, gdy pewne mniej formalne grupy pedagogiczne zajęły miejsce słynnych szkó ${ }^{74}$, przedstawiciele każdej tych grup - Paulus i Ulpian - należą do jurystów, u których najczęściej pojawia się interesujące nas sformułowanie. W związku z powyższym nie należy zbyt łatwo zgadzać się ze słowami A. Honoré, jakoby było ono jedynie „,prawdopodobnie ogranym przykładem szkoły sabiniańskiej”75. Jeżeli już było „ogranym przykładem”, to raczej nie należało tylko do jednej szkoły ${ }^{76}$.

Najciekawszego komentarza doczekało się użycie warunku si navis ex Asia venerit przez Gaiusa. A. Honoré poczytuje je jako jeden z argumentów potwierdzających fakt, że autor „Instytucji” był z pochodzenia Rzymianinem, który jednak na pewien czas udał się na prowincję, a powrócił do Rzymu między napisaniem drugiej i trzeciej księgi De verborum obligationibus ${ }^{77}$. Stąd w księdze drugiej używa zaskakującego nas nieco przykładu si navis ex Africa venerit, podczas gdy w księdze trzeciej powraca już do Italii, gdzie użycie tego warunku byłoby jak najbardziej przystające do okoliczności. A. Honoré sądzi, że Gaius pisał w Azji również komentarz do edyktu prowincjonalnego, w którym niezmienione pozostawił inne standardowe przykłady zawarte $\mathrm{w}$ cytowanym fragmencie D. $45,1,74^{78}$. W tym miejscu pojawia się pytanie, czy przejaw tak dynamicznego podejścia do słów si navis ex Asia venerit świadczy o tym, że był to warunek dobrze ugruntowany we wcześniejszych tekstach, czy może

${ }^{74}$ A.M. Honoré, Gaius, s. 39-40.

${ }^{75}$ [T] hey are probably stock examples from the Sabinian law school (...). A.M. Honoré, Gaius, s. 91. Jednak z przytoczonego fragmentu nie wynika niezbita pewność, że autor zalicza do takich przykładów również si navis ex Asia venerit, jako że pisze o tym w kontekście innych przykładów używanych z punktu widzenia mieszkańca Italii, cytując przy tym fragment Gaiusa zamieszczony w „Digestach” (D. 45,1,74), a pochodzący z jedynego znanego nam komentarza do edyktu prowincjonalnego. D. 45,1,74 (Gaius ks. 8 ad edictum provinciale): Stipulationum quaedam certae sunt, quaedam incertae. certum est, quod ex ipsa pronuntiatione apparet quid quale quantumque sit, ut ecce aurei decem, fundus Tusculanus, homo Stichus, tritici Africi optimi modii centum, vini Campani optimi amphorae centum.

${ }^{76}$ Choć oczywiście prawdą jest, że Prokulianin Celsus używa go w znanych nam tekstach tylko jeden raz, Pomponiusz stał „w rozkroku” między Sabinianami a Prokulianami, natomiast „grupy” Paulusa i Ulpiana nie do końca powielały stare kontrowersje, ale przenosiły dyskurs na nieco już inne płaszczyzny (A.M. Honoré, Gaius, s. 40).

${ }^{77}$ A.M. Honoré, Gaius, s. 95. Potwierdzałyby to także słowa z drugiej księgi De verborum obligationibus, mówiące o zobowiązaniu stypulacyjnym zawierającym przyrzeczenie ofiarowania jakiejś rzeczy w Kartaginie (D. 45,1,141,4).

${ }^{78}$ A.M. Honoré, Gaius, s. 90-91.

${ }^{79}$ Zakładając oczywiście, że żaden ze znanych nam tekstów nie był pierwszym przypadkiem jego użycia.

${ }^{80}$ D. 45,1,141,7 (Gaius ks. 2 de verborum obligationibus): Sed rursus mihi quidem pure aut Titio sub condicione stipulari possum. Contra vero si mihi sub condicione aut Titio pure, inutilis erit tota stipulatio, nisi in meam personam condicio extiterit, scilicet quia, nisi quod ad me vim acceperit obli- 
powstał bezpośrednio przed Gaiusem i nie stanowił jeszcze silnie ukształtowanej kolokacji ${ }^{79}$. Wydaje się po analizie semantyki i syntaktyki kontekstu, w jakim został umieszczony fragment D. $45,1,141,7^{80}$ zawierający warunek $s i$ navis ex Africa venerit, że druga odpowiedź jest bardziej prawidłowa. Być może futurum exactum powinno przy zmianie ugruntowanej frazy zostać zastapione czasem o nacechowaniu znaczeniowym mniej asertorycznym ${ }^{81}$, poza tym jednak połączenie frazy z innymi częściami zdania jest równie naturalne, jak w przypadku naszego warunku.

Oczywiście podając jako punkt wyjścia ustalenie, skąd pochodzi warunek $s i$ navis ex Asia venerit - jako że naturalnie jest ono ważne z punktu widzenia pozaprawnego kontekstu jego pierwotnego funkcjonowania - nie należy zapominać również o późniejszej tradycji tekstu. W tym miejscu chciałbym pokrótce dotknąc ciekawego zagadnienia. Kolejnym potwierdzeniem faktu, że linia przekazu źródeł niekoniecznie przebiegała w sposób identyczny z chronologią okresów życia poszczególnych jurystów, jest przykład Paulusa i Ulpiana. Pierwszy z nich, będąc bardzo wybitnym prawnikiem, a przy tym trochę starszym od drugiego i bardzo płodnym pisarsko ${ }^{82}$, powinien stanowić dla niego idealnego autora, którego dzieła są źródłem cytatów i ożywionej z nim dyskusji. Tymczasem, jak się dowiadujemy, Ulpian ani razu nie zacytował Paulusa nominatim ${ }^{83}$ - ten zresztą odpłacał mu pięknym za nadobne ${ }^{84}$. Być może ich „grupy” lub oni sami byli podmiotami ostrego sporu, nie tylko merytorycznego, ale przede wszystkim personalno-politycznego, przechodzacego nieraz $\mathrm{w}$ bardzo ostre antagonizmy? ${ }^{85}$ W takim razie Ulpian zaczerpnął użycie tego warunku prawdopodobnie od pierwszego znanego nam pokolenia prawników, które się nim posługiwało. Głównymi źródłami w jego pracy naukowej były bowiem „Digesta” Celsusa i Juliana, a także komentarze Pomponiusza Ad Sabinum i Ad edictum ${ }^{86}$.

Biorąc pod uwagę zupełnie odmienny charakter „Instytucji” justyniańskich i Fragmenta Vaticana, bezprzedmiotowe chyba byłoby omawianie tych dzieł w rozdziale poświęconym chronologii tekstów zawierających warunek si navis ex Asia venerit.

gatio, adiectio nihil potest valere. Hoc tamen ita demum tractari potest, si evidenter apparet pure Titii persona adiecta: alioquin cum ita stipulor: 'si navis ex Africa venerit, mihi aut Titio dari spondes?' Titii quoque persona sub eadem condicione adici videtur.

${ }^{81}$ Por. jednak warunek si caelum digito tetigerit.

${ }^{82}$ Paulus miał napisać ponad trzysta ksiąg, które w pewnej części zostały przejęte do „Digestów" justyniańskich i stanowią około 1/6 tej kompilacji. W. Litewski, Jurysprudencja ..., s. 148.

${ }^{83} \mathrm{~W}$. Litewski, Jurysprudencja ..., s. 154 in fine.

${ }^{84}$ A.M. Honoré, Ulpian, Oxford 1982, s. 218.

${ }^{85}$ Por. A.M. Honoré, Gaius, s. 40; tenże, Ulpian, s. 214-219, gdzie autor wyraża jednak przekonanie o dużym prawdopodobieństwie tego, że Ulpian korzystał z dzieł Paulusa po prostu je kopiując. Według niego brak cytowań można zrzucić na karb obowiązujących wtedy zwyczajów dotyczących wzajemnego odnoszenia się poszczególnych jurystów do swoich pism.

${ }^{86}$ A.M. Honoré, Ulpian, s. 206 in fine. 
III. Charakter warunku. Uważny czytelnik powinien najpóźniej do tego miejsca powziąć słuszne wątpliwości: dlaczego tak drobiazgowo roztrząsany był temat kontekstu historycznego, w jakich mógł pojawić się tak sformułowany warunek? Przecież jest to tylko mniej lub bardziej szkolny przykład użycia określonych, powtarzanych bezrefleksyjnie słów, które poprzez niezbyt wyszukaną treść mają zwrócić uwagę nie tyle na swoje brzmienie, ile raczej na problem prawny, który przedstawiony jest przy ich użyciu ${ }^{87}$. Do tego stopnia był on oderwany od jakichkolwiek okoliczności faktycznych, że mógł go użyć nawet Anglik żyjący w XIII wieku. Mowa tu o Henrym de Bracton, autorze przesławnego dzieła Tractatus de Legibus et Consuetudinibus Regni Angliae, zwanego „koroną i kwiatem średniowiecznej jurysprudencji angielskiej” ${ }^{8}$. Bracton w swoim dziele chciał zawrzeć całość prawa angielskiego ${ }^{89}$, czerpiąc przy tym w znacznej części z dorobku rzymskich jurystów i ich następców, zwłaszcza glosatora Azona, choć wpływ prawa rzymskiego na jego dzieło po dziś dzień jest dyskutowany. Opinie naukowców są w tym temacie rozbieżne do tego stopnia, że niektórzy mówią o wprost o plagiacie ${ }^{90}$, a inni stwierdzaja, że w całym dziele prawo rzymskie nie stanowi materiału mogącego zapełnić chociażby trzy strony ${ }^{91}$. Popierający to pierwsze stanowisko utrzymują, że Bracton przy pisaniu De Legibus opierał się przede wszystkim na „Kodeksie”, „Digestach” i „Instytucjach”, a także na Summa Azonis ${ }^{92}$. Niezależnie od niejednolitości tych opinii faktem jest jednak to, że angielski jurysta aż trzykrotnie $^{93}$ używa jako ilustracji swoich tez warunku si navis ex Asia venerit.

${ }^{87}$ The case of the ship from Asia is, of course, academic. Yet we can see that the results of alternative conditions were discussed in connection with actual practical problems, but by reference to the ship case. A. Rodger, Emptio Perfecta Revisited..., s. 344, przyp. 30.

${ }^{88}$ W. Pollock, F. Maitland, The History of English Law Before the Time of Edward I, t. 1, Cambridge 1968, s. 206.

${ }^{89}$ Zob. G. Woodbine, The Roman Element in Bracton's De Adquirendo Rerum Dominio, 31 „The Yale Law Journal” 8 (1922), s. 828.

${ }^{90}$ And, to take a phenomenon of smaller interest, it assists us, though only partially to understand the plagiarisms of Bracton. That an English writer of the time of Henry III. should have been able to put off on his countrymen as a compendium of pure English law a treatise of which the entire form and a third of the contents were directly borrowed from the Corpus Juris, and that he should have ventured on this experiment in a country where the systematic study of the Roman law was formally proscribed, will always be among the most hopeless enigmas in the history of jurisprudence; but still it is something to lessen our surprise when we comprehend the state of opinion at the period as to the obligatory force of written texts, apart from all consideration of the source whence they were derived. H.S. Maine, Ancient Law, New York 1871, s. 79. Maine'a cytują także G. Woodbine, The Roman..., s. 828-829; Ł. Marzec, Prawo rzymskie w systemie anglosaskim, „Studenckie Zeszyty Prawnicze TBSP UJ" 5 (2001), s. 88-89.

${ }^{91}$ G. Woodbine, The Roman..., s. 829, który przytacza tutaj słowa J. Reevesa [w:] History of the English Law, London 1787, s. 89.

92 Por. G. Woodbine, The Roman ..., s. 836; Ł. Marzec, Prawo rzymskie ..., s. 88-91.

${ }^{93}$ Por. http://hls15.law.harvard.edu/bracton/Common/SearchPage.htm (20 grudnia 2011). 
Rozważmy kolejno te przykłady:

Bracton, fo. 19: Item si conditio casualis fuerit, ut si dicam, Do tibi talem rem si navis venerit ex Asia, vel si Titius consul factus fuerit, erit donatio in pendenti quia huiusmodi donationes dependent ex insidiis fortuna $e^{94}$.

Podobnie, jeśli zaistnieje warunek kazualny, jaki przytoczę: 'dam ci taką rzecz, jeśli statek przypłynie z Azji lub jeśli Tytus zostanie konsulem', darowizna będzie zawieszona, gdyż tego rodzaju darowizny zależne są od pułapek losu.

O ile George Woodbine podkreśla oczywistość proweniencji słów obydwu warunków umieszczonych w De Adquirendo Rerum Dominio ${ }^{95}$ i ich mechaniczne tam zastosowanie bez względu na zmieniony kontekst, w jakim zostały użyte, o tyle zastanawia się on skąd pochodzić może sformułowanie insidiae fortunae. Jego rodowód bowiem taki jasny już nie jest. Zaraz potem jednak precyzuje ${ }^{96}$, że można łączyć ten fragment dzieła $\mathrm{H}$. de Bractona z C. $6,27,6^{97}$ i C. 6,51,1,798 - fragmentami „Kodeksu” Justyniana, w których mowa jest o warunku kazualnym. Pomimo tak radykalnie różnych okoliczności i nieco innej faktycznej możliwości spełnienia warunku, nie przechodzi on do kategorii warunków niemożliwych, ani - biorąc pod uwagę klasyfikację teoretyczną warunków - nie zmienia raczej swojej przynależności do żadnego z członów podziału wyszczególnionego według jakiekolwiek kryterium. Zmiana okoliczności faktycznych być może zmniejsza nieco prawdopodobieństwo jego ziszczenia, jednak nie zmienia to w żaden sposób natury dekodowanej z tekstu $H$. de Bractona normy prawnej. G. Woodbine

${ }^{94}$ Ten tekst i następny są cytowane również przez G. Woodbine'a, The Roman ..., s. 839. Na marginesie można tutaj zauważyć, że występujący tu łącznie z naszym warunkiem warunek si Titius consul factus fuerit pojawia się w samych „Digestach” ponad dwadzieścia razy. Zob. np.: D. $21,2,46,2$; D. $35,1,11,1$; D. $45,1,63$; D. 45,1,64; D. 45,1,126pr.; D. 46,7,13pr.

${ }^{95}$ Część dzieła Bractona, która wyszczególniona jest w pozycjach drukowanych. G. Woodbine, The Roman..., s. 831.

${ }^{96}$ Ibidem, s. 839.

${ }^{97}$ (...) libertatem autem sub condicione ei donavit, si quidem condicio talis sit, quae in potestate servi posita est: ille autem eam neglexerit minimeque compleverit, et libertate eum et hereditate sua culpa defraudari. Sin autem casualis est condicio et ex fortunae insidiis defecerit, tunc humanitatis intuitu libertatem quidem ei omnimodo competere, hereditatem autem, si quidem solvendo sit, ad alios venire, quos leges vocabant, si non aliquis fuisset substitutus. (...).

${ }^{98}$ Sin autem aliquid sub condicione relinquatur vel casuali vel potestativa vel mixta, quarum eventus ex fortuna vel ex honoratae personae voluntate vel ex utroque pendeat, vel sub incerta die, expectare oportet condicionis eventum, sub qua fuerit derelictum, vel diem, ut tunc cedat, cum vel condicio impleatur vel dies incertus extiterit. Quod si in medio is, qui ex testamento lucrum sortitus est, decedat vel eo superstite condicio defecerit, hoc, quod ideo non praevaluit, manere disponimus simili modo apud eos, a quibus relictum est, nisi et hic vel substitutus relictum accipiat vel coniunctus sive heres sive legatarius hoc sibi adquirat, cum certi iuris sit et in institutionibus et legatis et fideicommissis et mortis causa donationibus posse substitui. 
zauważa również, że w odróżnieniu od innych przykładów zaczerpniętych słowo w słowo z tekstów jurystów rzymskich, na przykład sztampowego warunku si coelum digito tetigeris, po którym standardowo następują rozważania dotyczące condicio impossibilis, $\mathrm{H}$. de Bracton zgrabnie wkomponowuje si navis... W tak ulubioną przez niego formułkę zwracającą uwagę na pułapki, jakie zastawia na nas fortuna ${ }^{99}$.

O tym, że warunek si navis ex Asia venerit jest popularny nawet pod koniec wieków średnich, zapewnia nas również kolejny fragment De Legibus:

Bracton, fo. 47: Ut si dicatur, Do tali talem rem si navis venerit ex Asia, vel si comes Ricardus effectus fuerit rex Alemanniae, vel si hoc fecerit vel non fecerit: talis donatio perfectanon erit donec ita sit vel non sit, cum dependeat ex insidiis fortunae, et existente condicione perfecta erit facta traditione, quae si non fiat habebit donatarius actionem ex conventione.

Jeśli byłoby powiedziane: dam takiemu to taką rzecz, jeżeli statek przypłynie z Azji, lub jeżeli komes Ryszard zostanie królem Niemiec, lub jeżeli zrobi to bądź nie zrobi - taka darowizna nie będzie kompletna, dopóki tak będzie lub tak nie będzie, bo zależy to od pułapek fortuny; po spełnieniu warunku będzie kompletna, o ile nastappi wręczenie, a jeśli ono nie nastąpi - obdarowanemu przysługiwać będzie powództwo z umowy.

Pomijając niezwykle barwne i oddziałujące na wyobraźnię zestawienie podróży statku z Azji i starania o koronę cesarską, co najdobitniej chyba świadczy o bardzo wysokim współczynniku akomodacji naszego warunku, należy stwierdzić, że prawdopodobnie jest to trawestacja fragmentu „Digestów” D. 18,6,8,1 - przy czym wydaje się, że H. Bracton nie do końca przeanalizował tutaj znaczenie współwystępowania dwóch warunków, które - odniesione do płaszczyzny faktów - do końca wypełniają przestrzeń możliwości ${ }^{100}$, przez co w sferze normatywnej znacznie modyfikowany jest reżim tego accidentale negotii. Następstwem zaś tego mogą być oczywiście praktyczne konsekwencje dla przejścia na nabywcę przedmiotu własności i ryzyka związanego z przypadkową utratą rzeczy.

Ostatnim fragmentem z dzieła średniowiecznego jurysty angielskiego dotyczącym si navis ex Asia venerit jest nieomalże dosłowny cytat z „Instytucji” Justyniana (I. 3,19,14) ${ }^{101}$ :

${ }^{99}$ Por. G. Woodbine, The Roman..., s. 839.

${ }^{100}$ Por. A. Rodger, Emptio Perfecta Revisited..., passim. Autor De Legibus uzasadnia niekompletność czynności prawnej tym, że dependeat ex insidiis fortunae.

${ }^{101}$ Zob. infra. 
Bracton, fo. 100: Item erit inutilis si quis ita stipulatus fuerit, Si navis venerit de Asia hodie dare spondes? quia praepostere concepta est. Sed tamen, licet praepostera fuerit, non erit reicienda.

Tak również nieskutecznym będzie, gdy ktoś odbierze stypulację sformułowaną w taki sposób: jeżeli statek przybędzie z Azji - czy przyrzekasz dać dzisiaj? ponieważ jest ona uczyniona w sposób opaczny. Jednak choć będzie dokonana opacznie, nie będzie odrzucona.

Wiarygodność użycia tej części „Instytucji” przez Bractona jest w nauce podważana $^{102}$. Wypada się z tym zgodzić, gdyż inna jest technika inkorporacji tego fragmentu do tekstu w stosunku do dwóch przytaczanych wcześniej. $\mathrm{Z}$ jednej strony bowiem widzimy tutaj bardziej średniowieczną lekcję de Asia zamiast ex Asia lub zupełnie bezprzyimkowej Asia w narzędniku ${ }^{103}$. Z drugiej zaś oprócz drobnych zmian redakcyjnych, np. usunięcia z tekstu wzmianki o ,sławnej pamięci Leonie”, korekty stipulatus erat na stipulatus fuerit etc., nie widać tutaj wpływu oryginalnej myśli jurysty. Nawet jednak przyjmujac, że parafraza nie jest oryginalnym dziełem Bractona, świadczy to o tym, że interpolator miał w ręku kompilację justyniańską i mimo uzasadnionego usunięcia imienia cesarza Leona nie miał ochoty pozbywać się innych kojarzących się z Rzymem zwrotów.

Powróćmy zatem do pytania, od którego początek swój bierze niniejsza część artykułu: dlaczego dość istotne znaczenie miało zastanowienie się nad okolicznościami pozaprawnymi powstania tego warunku, jeżeli z przedstawionych rozważań jasno widać, że jest to wyłącznie akademicka formułka, z której pomocą dowolnie można zaradzić brakowi własnej pomysłowości w konstruowaniu przykładów albo po prostu przejąć ją i skupić się na rozważaniu o wiele ciekawszych kwestii? Być może dlatego, że istnieją również inne świadectwa, w których obok roztrząsania zagadnień prawnych dokonane zostaje pośrednie usytuowanie - prawdopodobnie nieświadome i z pewnością marginalne wobec zasadniczych problemów będących przedmiotem namysłu jurystów faktycznej treści tego warunku w kontekście możliwości jego spełnienia. Poza tym, być może, warunek ten różni się od większości innych, które dają się odnaleźć w rzymskich tekstach prawnych ${ }^{104}$.

Przypomnijmy, że biorąc pod uwagę okoliczności, w jakich tworzyli rzymscy przedstawiciele nauki prawa, u których si navis ex Asia venerit pojawia się po raz pierwszy, był to warunek typowy, dosyć łatwy do spełnienia. Nie stoi

${ }^{102}$ Zob. G. Woodbine (ed.), De Legibus et Consuetudinibus Angliae, New Haven 1922, t. 2 , s. 286 .

${ }^{103}$ Taka wersja nie występuje jednak nigdy nawet w tekstach rzymskich.

${ }^{104}$ Por. infra. 
temu na przeszkodzie tekst Ulpiana z dwudziestej czwartej księgi komentarza do Sabinusa:

D. 26,2,8,3 (Ulpian ks. 24 ad Sabinum): In tutoris dationem utrum levissima condicio an novissima, ut in legato, spectanda est? Ut puta 'Titius cum poterit tutor esto': 'Titius si navis ex Asia venerit tutor esto'. Et Iulianus libro vicesimo digestorum recte scripsit novissimam scripturam esse spectandam.

Czy przy wyznaczaniu opiekuna należy brać pod uwagę warunek najlżejszy [do spełnienia], czy najpóźniejszy, jak w przypadku legatu? Na przykład: 'Tytus, jeśli będzie mógł, niech zostanie opiekunem'; ‘Tytus, jeżeli statek przybędzie z Azji, niech zostanie opiekunem'. Julian w księdze dwudziestej Digestów ${ }^{105}$ słusznie napisał, że należy trzymać się ostatniego warunku.

Ulpian mówi tutaj, w jaki sposób należy interpretować znaczenie wyznaczenia opiekuna pod dwoma nierównobrzmiącymi warunkami. Pomimo że rzymskie prawo spadkowe nieprzychylnie patrzyło na dodawanie accidentalia negotii do rozrządzeń testatora, zasada ta nie dotyczyła ustanowienia i odwołania ustanowienia tutora. Nie dość że - w przeciwieństwie do ustanowienia dziedzica - można było go wyznaczyć także za pomocą kodycylu ${ }^{106}$, to w dodatku mógł on być wyznaczony nawet pod warunkiem lub z terminem rozwiązującym ${ }^{107}$. Warto zauważyć, że pomimo braku sprzeczności pomiędzy tymi dwoma warunkami, jurysta nie zastanawia się nawet nad możliwością ich kumulacji. Bardzo ciekawy jest tutaj fakt, że Ulpian powołuje się na Juliana, który był szczególnie zainteresowany problemami związanymi $\mathrm{z}$ warunkiem $^{108}$, jednak $\mathrm{z}$ tekstu wcale nie wynika, że ten drugi użył w cytowanym dziele dokładnie tego samego sformułowania. Mogło tutaj chodzić po prostu o przejęcie samego poglądu na rozstrzyganą kwestię prawną, nie jest więc powiedziane, że Ulpian zapożyczył zwrot si navis ex Asia venerit bezpośrednio od Juliana. Oprócz tego wcale nie można mieć pewności, czy pierwszy z wymienionych warunków to conditio levissima, a drugi to conditio novissima. W szczególności obydwa mogą się bowiem odnosić do conditio novissima. Nie ma tutaj na przykład sformułowania illa... haec (conditio), które zdecydowanie ułatwiłoby interpretację tekstu przez pewność atrybucji odpowiedniego przymiotnika do każdego z dwóch zwrotów warunkowych. Przyjmijmy jednak na co zdaje się wskazywać prima facie tekst - że warunkiem łatwiejszym do spełnienia jest cum poterit, a warunkiem najpóźniejszym si navis ex Asia vene-

${ }^{105}$ O. Lenel, Palingenesia..., t. 1, szp. 372, Iulianus nr 318.

${ }^{106}$ D. $26,2,8$ pr.

${ }^{107}$ D. $26,2,8,2$ : Tutorem autem et a certo tempore dare et usque ad certum tempus licet et sub condicione et usque ad condicionem.

${ }^{108}$ Zob. A. Rodger, Emptio Perfecta Revisited..., s. 339. 
rit. Taka interpretacja oczywiście nie orzeka o tym, że si navis... jest w sposób bezwzględny mało prawdopodobny, ale jedynie to, że jest trudniejszy do spełnienia od warunku cum poterit. Nic jednak nie wskazuje na to, by jurysta chciał skontrastować jeden z najprostszych do spełnienia warunków z warunkiem, który wypełnić bardzo trudno. Gdyby bowiem chciał tak zrobić, mógłby posłużyć się chociażby nie mniej utartym, za to o wiele bardziej oczywistym $s i$ coelum digito tetigerit.

Zupełnie inną sytuację mamy w D. 28,5,68, jednak wygląda to na oczywisty przejaw favor testamenti, niezależnie od tego, że we fragmencie tym conditio novissima występuje zarazem $\mathrm{w}$ charakterze conditio levissima:

D. 28,5,68 (Pomponiusz ks. 2 ad Quintum Mucium): Si ita scriptum fuerit: 'Tithasus si in Capitolium ascenderit, heres esto: Tithasus heres esto', secunda scriptura potior erit: plenior est enim quam prior.

Gdyby tak było napisane: 'Jeżeli Tithasus wejdzie na Kapitol, niech zostanie dziedzicem'; 'Tithasus niech zostanie dziedzicem' - drugie z tych postanowień będzie miało większą moc, jest bowiem pełniejsze od pierwszego.

Kolejny z fragmentów, który wskazuje na pośrednie choćby zainteresowanie rzeczywistym funkcjonowaniem warunku si navis..., pochodzi z tego samego komentarza ad Sabinum Ulpiana i brzmi następująco:

D. 35,1,2 (Ulpian ks. 5 ad Sabinum): Condicionum quaedam sunt, quae quandoque impleri possunt etiam vivo testatore, ut puta 'si navis ex Asia venerit', nam quandoque venerit navis, condicioni paritum videtur: quaedam, quae non nisi post mortem testatoris 'si decem dederit' 'si capitolium ascenderit': nam ut paruisse quis condicioni videatur, etiam scire debet hanc condicionem insertam: nam si fato fecerit, non videtur obtemperasse voluntati.

Wśród warunków zdarzają się takie, które niekiedy mogą być wypełnione także za życia testatora, jak na przykład: 'jeżeli statek przybędzie z Azji', bo ilekroć przypłynie statek, będzie to traktowane tak, jakby warunek został wypełniony ${ }^{109}$; niektóre zaś nie mogą być wypełnione [kiedy indziej], jak tylko po śmierci testatora, na przykład 'jeżeli da dziesięć', 'jeżeli wejdzie na Kapitol'; ponieważ aby mogło być uznane, że ktoś wypełnił warunek, musi on przecież wiedzieć, że taki warunek został ustanowiony. Jeżeli bowiem uczynił [to] przypadkiem, nie wydaje się, aby spełnił warunek.

${ }^{109}$ Autor expressis verbis stwierdza możliwość spełnienia warunku bez żadnych przeszkód.

${ }_{110}$ O. Lenel, Palingenesia..., t. 2, szp. 1031, Ulpianus nr 2466.

${ }^{111}$ D. 28,7,1: Sub impossibili condicione vel alio mendo factam institutionem placet non vitiari. 
Położenie palingenetyczne tego tekstu jest rozbieżne z kolejnością „Digestów", a więc prawdopodobnie kompilatorzy justyniańscy wyciągnęli go z jego oryginalnego kontekstu. Otto Lenel umieszcza go bowiem w miejscu, gdzie rozważany jest problem postanowienia sporządzonego wadliwie ${ }^{110}$, przede wszystkim „pod warunkiem niemożliwym lub z innym błędem”"111. O ile Ulpian wydaje się pobłażliwy dla wszelakich przejawów niedociągnięć przy umownym konstruowaniu danego elementu treści czynności prawnej, to jednak zdecydowanie sprzeciwia się uznaniu warunku za wypełniony, jeżeli wypełnienie go leżało w gestii osoby, która ma otrzymać coś ze spadku. Rodzi się ciekawe pytanie, czy dotyczy to również osoby trzeciej. Wydaje się, że nie, jako że gdyby tą osobą trzecią był np. magister navis ${ }^{112}$, który nieświadomie wypełnił warunek si navis ex Asia venerit - warunek mimo to uznany zostałby za wypełniony. Abstrahując jednak od rozważań opartych na niepotwierdzonym w tekście stanie faktycznym, należy stwierdzić, że Ulpian dokonuje tutaj ciekawego zabiegu ${ }^{113}$. Odrywa on bowiem wykładnię treści pewnego elementu czynności prawnej od powodu jego ustalenia, ustalając a limine, że osobie ustanawiającej warunek zależało nie tylko na efekcie, jaki przez to miała uzyskać, ale przede wszystkim na tym, żeby ten, kto wykonał warunek, wykonał go świadomie. Niemal identyczną sytuację ilustruje Ulpian w dwudziestej trzeciej księdze komentarza do Sabinusa:

D. 35,1,10,1 (Ulpian ks. 23 ad Sabinum): Si sic legatum sit 'si navis ex asia venerit' et ignorante testatore navis venerit testamenti facti tempore, dicendum pro impleta haberi. Et si cui sic legatum est 'cum pubes erit', simili modo hoc erit dicendum.

Jeśli tak dokonanoby legatu: ‘jeżeli statek przybędzie z Azji’ i testator nie wiedziałby o tym, że statek przyby $\mathfrak{1}^{114} \mathrm{z}$ Azji w czasie sporządzania testamentu, jest on uznawany za wypełniony. Jeśli zaś komuś coś zapisano w drodze legatu 'gdy będzie dojrzały', tak samo będzie powiedziane.

${ }^{112} \mathrm{~W}$ kwestii stanowiska magistri navis zob. np. T. Palmirski, Pozaumowna odpowiedzialność armatorów, oberżystów i właścicieli stajen w przypadku szkód wyrzqdzonych osobom korzystajacym z ich ustug, [w:] Honeste vivere... Księga pamiqtkowa ku czci Profesora Władysława Bojarskiego, Torun 2001, s. 154 i powoływana tam literatura.

${ }^{113}$ Tekst jest przez Index Interpolationum uznany za nieautentyczny w całości lub od słów nam quandoque do videtur. L. Mitteis, E. Levy, E. Rabel, Index Interpolationum quae in Iustiniani Digestis inesse dicuntur, Weimar 1931, t. 2, szp. 305.

${ }^{114}$ Tutaj venerit występuje w formie coniunctivi perfecti.

${ }^{115}$ Całość D. 35,1,10,1 również jest podejrzewana o bycie interpolacją. L. Mitteis, E. Levy, E. Rabel, Index Interpolationum ..., Weimar 1931, t. 2., szp. 307.

${ }^{116}$ Używam tu tego terminu w cudzysłowie, mając świadomość, że pojęcie causa odnosi się do całości czynności prawnej, a nie jej elementów, a także fakt, iż może ono być stosowane tylko do czynności prawnych rozporządzających, więc np. omawiane wcześniej ustanowienie opiekuna nie mogłoby być pod tym kątem analizowane. Podobny pod tym względem był na przykład, moim zdaniem, warunek si decem dederit. 
Moim zdaniem oznacza to ni mniej, ni więcej tylko to, że - o ile fragmenty te są autentyczne ${ }^{115}$ - Ulpian przejmuje z tekstów wcześniejszych jurystów jedynie samo brzmienie si navis ex Asia venerit, nie dostrzegając jego funkcjonowania w dziełach poprzedników. Sądzę bowiem, że warunek ten u swego zarania odznaczał się swego rodzaju „kauzalnością" ${ }^{116}$. Biorąc pod uwagę wcześniejsze uwagi, mające wykazać jego znaczne zakorzenienie się w rzeczywistości pozaprawnej, można chyba postawić następującą hipotezę: jeżeli przyjęlibyśmy, że nie mamy do czynienia z sytuacją całkowicie wymyśloną na potrzeby rozważań jurysty ${ }^{117}$, warunek si navis... został nieświadomie pomyślany przez tego, kto użył go po raz pierwszy, jako realizujący pewien cel ściśle gospodarczy, bardzo zbliżony w swej treści do celu, który implikuje użycie pojęcia causa. Oczywiście, wszystkie warunki jako elementy treści czynności prawnej mają realizować materialne lub niematerialne interesy tego, kto je w tej czynności zastrzega. Mówiąc jednak o kauzalnym powiązaniu, mam tutaj na myśli fakt, że ktoś na przykład zabezpieczał sprzedaż jakiegoś artykułu zastrzegając, że czynność będzie miała miejsce, jeżeli statek z tym towarem przypłynie z Azji i tym samym uwalniał się on od odpowiedzialności odszkodowawczej (na przykład pożyczkodawca w kontrakcie foenoris nautici). Istniało więc genetyczne powiązanie pomiędzy tym, że statek przypłynie z Azji, a czynnością dokonaną pod warunkiem. Oczywiście spełnienie tego warunku nie mogłoby w takiej konstelacji być zależne jedynie od drugiej strony umowy - niespełnienie go bowiem mogłoby skutkować w tym przypadku skorzystaniem przez tego, kto zastrzegł warunek, ze zwykłego ius retentionis, a przy jednostronnym obowiązku świadczenia byłoby to jeszcze bardziej trywialne. Sytuację nieco inną niż w ostatnio powołanym fragmencie możemy dostrzec w trzydziestej pierwszej księdze „Digestów” Juliana:

D. 35,1,21 (Julian ks. 31 digestorum): Multum interest, condicio facti an iuris esset: nam huiusmodi condiciones 'si navis ex Asia venerit' 'si Titius consul factus erit', quamvis impletae essent, impedient heredem circa adeundam hereditatem, quamdiu ignoraret eas impletas esse: quae vero ex iure venient, in his nihil amplius exigendum, quam ut impletae sint. Veluti si quis se filium familias existimat, cum sit pater familias, poterit adquirere hereditatem: quare et ex parte heres scriptus, qui ignorat, an tabulae testamenti apertae sint, adire hereditatem poterit.

Duże znaczenie ma, czy jest [to] warunek faktyczny, czy prawny, ponieważ warunki typu 'jeżeli statek przybędzie z Azji', 'jeżeli Tytus zostanie konsulem', chociaż byłyby wypełnione, będą dziedzicowi przeszkadzały w nabyciu spadku tak

${ }^{117}$ Por. np. D. Johnston, Roman Law in Context, Cambridge 1999, s. 24-29, gdzie prowadzone są rozważania o tym, jak dalece stany faktyczne opisane w „Digestach” odzwierciedlają rzeczywiste stosunki gospodarcze. 
długo, jak nie będzie on wiedział, że są wypełnione. Te zaś, które wywodzą się $\mathrm{z}$ prawa, nie wymagają niczego więcej, jak tylko tego, żeby były wypełnione. Na przykład, jeżeli ktoś o sobie sądzi, że jest filius familias, jeżeli [w rzeczywistości] byłby pater familias, może nabyć spadek. $Z$ tego też powodu dziedzic ustanowiony ex parte, który nie wie, czy testament został otwarty, będzie mógł nabyć spadek.

W tym przypadku wypełnienie treści warunku nie leży w gestii osoby mającej być beneficjentem skutków prawnych związanych z takim zdarzeniem prawnym. Nie chodzi więc o to, aby była ona świadoma tego, że dokonuje czynności będącej przedmiotem zastrzeżenia dokonanego przez spadkodawcę, lecz o to, żeby wiedziała, iż warunek zawieszający już się ziścił ${ }^{118}$. Niestety, Ulpian nie snuje w tej księdze swoich „Digestów”, poświęconej testamentom, żadnych dalszych rozważań o podziale na warunki faktyczne i prawne.

Mówiąc o charakterze warunku, nie sposób nie odnieść się chociażby pokrótce do zagadnienia form gramatycznych orzeczeń, które występują w zdaniach tworzących okres warunkowy, a co za tym idzie do pewnych aspektów semantycznych, będących wynikiem takiego konstruowania wypowiedzi. Wiążą się z tym dwa zagadnienia - jedno dość mało skomplikowane, drugie o nieco donioślejszej problematyce.

Vocabularium Iurisprudentiae Romanae uznaje frazę si navis ex Asia venerit sive non venerit ${ }^{119}$ za jeden ze zwrotów z łącznikiem sive zawierającym coniunctivus perfecti ${ }^{120}$. Tak samo traktowany jest warunek sive illud factum fuerit $^{121}$. W cytowanym już artykule A. Rodger wyraża zdecydowaną dezaprobatę wobec takiego stanowiska ${ }^{122}$. Według niego jest to oczywista pomyłka, zwłaszcza biorąc pod uwagę to, że w innym tomie Vocabularii (s.v. illud) użyty w drugim z tych warunków zwrot factum fuerit zostaje zamieniony na factum erit, czyli tratowany jest jako zwykłe futurum primum ${ }^{123}$. Pozostaje zgodzić się z autorem, gdyż interpretacja tej formy jako coniunctivi perfecti nie korespondowałaby $\mathrm{w}$ tekstach prawnych $\mathrm{z}$ naturą warunku ${ }^{124}$, a nic nie wskazuje na to, by którykolwiek z jurystów chciał potraktować ten warunek jako niewłaściwy, na przykład już spełniony.

${ }^{118}$ Być może cały fragment jest nieautentyczny. L. Mitteis, E. Levy, E. Rabel, Index Interpolationum ..., t. 2, szp. 308 .

${ }^{119}$ D. $18,6,8,1$.

${ }^{120}$ VIR, Berlin 1917, t. 5, fasc. 2, szp. 581, s.v. sive.

${ }^{121}$ VIR, op. cit., t. 5, fasc. 2, szp. 580, s.v. sive.

${ }^{122}$ Emptio Perfecta Revisited..., s. 338, 340-341.

${ }^{123}$ VIR, Berlin 1931, t. 3, fasc. 2, szp. 376, s.v. illud.

${ }^{124}$ Tak też A. Rodger, Emptio Perfecta Revisited..., s. 338.

${ }^{125}$ Tzn. zdanie będące poprzednikiem okresu warunkowego, w którym wyrażona jest hipotetyczność. Zdanie będące następnikiem nosi nazwę $\square \pi \square \delta$ oбỉ.

${ }^{126}$ Inne możliwe modi to: modus potentialis - według nadawcy takiego wyrażenia możliwe jest zajście zdarzenia opisanego w $\pi \rho \square$ табỉ; modus irrealis - nadawca orzeka o niemożliwości spełnienia się takiego warunku, a także modi mixti. 
Znacznie ciekawsza jest kwestia modalności okresu warunkowego zawierającego orzeczenie venerit. Jako że $\pi \rho \square \tau \alpha \sigma i{ }^{125}$ zawiera formę trybu wskazującego (indicativus futuri exacti), należy przyjąć, że mamy tu do czynienia $\mathrm{z}$ modalnością nienacechowaną (modus realis $)^{126}$. Oznacza to, że nadawca wypowiedzi w „obiektywny” sposób wyraża jedynie powiązanie między poprzednikiem a następnikiem okresu warunkowego, bez wypowiadania się na temat prawdopodobieństwa jego spełnienia. O ile takie zastosowanie powyższego modi przy okazji warunku si navis ex Asia venerit jest całkowicie uzasadnione, to chyba specyficzną cechą rzymskiego języka prawnego, mającą być może wyrażać pewien dystans do pozanormatywnej rzeczywistości, jest niejednokrotne prezentowanie przykładu condicio impossibilis z zastosowaniem modus realis ( $\mathrm{np}$. si coelum digito tetigerit) ${ }^{127}$. Wynika stąd stwierdzenie, że sama forma gramatyczna warunku si navis... raczej mało mówi nam o jego faktycznym charakterze ${ }^{128}$. Na pokrewne tematycznie zagadnienie natknął się R. Zimmermann, który analizował teksty Gaiusa i Ulpiana związane z lex Aquilia $^{129}$. Tam znaczenie miały formy gramatyczne czasownika sum, esse: fuit, fuerit oraz erit. Takie badania pokazują, jak często niewielka choćby okoliczność, która została przeoczona, albo najmniejsza nadinterpretacja wyników dociekań filologicznych może prowadzić do zupełnie opacznego rozumienia tekstu prawnego ${ }^{130}$.

Począwszy od „Instytucji” justyniańskich, zaprezentuję trzy teksty, które będą odnosić się do niewłaściwego dołączenia warunku do treści czynności

${ }^{127}$ Jest to standardowa formuła rzymskich warunków, niezależnie od tego, co znajduje się w ich treści. Mogą one opisywać nie tylko czynność faktyczną, np. si ascenderit, si factus fuerit, ale również prawną, np. si manumisserit, si emancipaverit, si venierit, si non nupserit etc. O tym, że raczej

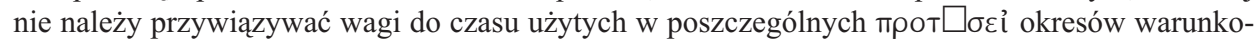
wych, upewniają nas liczne zmiany czasów i trybów, które tam występują bez związku z pozanormatywną rzeczywistością. O ile w wykazującej dużą fluktuację form gramatycznych czasownika grece byłoby to normalne, to jednak rygorystyczna gramatyka łacińska zdecydowanie nie dopuszczałaby do tego, gdyby juryści faktycznie chcieli rozważać użycie tych form. To, że tego nie robili, raczej potwierdza tylko fakt, iż nie było to dla nich prawie w ogóle ważne.

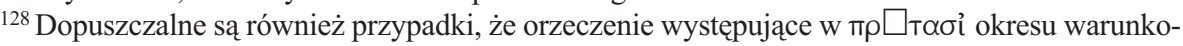
wego w modus irrealis jest wyrażone w indikatiwie. Mamy z tym do czynienia na przykład wtedy, gdy w $\square \pi \square \delta o \sigma i ̉$ wyrażone jest w formie peryfrastycznej (omownej), lub gdy występuje tam nacechowanie modalne (np. czasowniki nolo, volo, malo, oportet, debeo etc.) albo indicativus $\mathrm{w} \pi \rho \square$ т $\alpha \sigma i$ ma za zadanie opisać wydarzenie w trybie irrealis, którego uniknięto o mały włos (forma emfatyczna). Po pierwsze jednak taki indicativus nie występuje w futurum exactum, a po drugie wyjątki te nie pasują do omawianej sytuacji.

${ }^{129}$ R. Zimmermann, The Law..., s. 963.

${ }^{130} \mathrm{Z}$ podobnym problemem spotykamy się również na przykładzie lex Atinia, ustawy z okresu późnej republiki. Na jej gruncie powstać miał spór, czy zwrot quod subreptum erit dotyczy czasu przyszłego, czy przeszłego. Nawet przy tak „oczywistych”, jak mogłoby się wydawać, przypadkach, często jesteśmy skazani na domysły. Por np. W. Wołodkiewicz, Europa i prawo rzymskie, Warszawa 2009, s. 404-405; A. Calzada, A propósito de la retroactividad de la Lex Atinia de rebus subreptis, RIDA 57 (2010), s. 75-92.

${ }^{131}$ Zob. supra. 
prawnej. Pierwszy przywołany zostanie fragment, na którym oparł się Henry de Bracton albo któryś $\mathrm{z}$ jego kompilatorów ${ }^{131}$ :

I. 3,19,14: Item si quis ita stipulatus erat: 'si navis ex Asia venerit, hodie dare spondes?' inutilis erat stipulatio, quia praepostere concepta est. sed cum Leo inclytae recordationis in dotibus eandem stipulationem, quae praepostera nuncupatur non esse reiciendam existimavit, nobis placuit et huic perfectum robur accommodare, ut non solum in dotibus, sed etiam in omnibus valeat huiusmodi conceptio stipulationis.

Ponadto jeśli ktoś odebrał stypulacyjne przyrzeczenie następująco: 'jeśli przybędzie okręt z Azji, czy przyrzekasz dać mi dzisiaj?' - stypulacja była bezskuteczna, ponieważ została ułożona opacznie. Lecz gdy sławnej pamięci Leon uznał, że przy posagach ta sama stypulacja, która zwana jest opaczną, nie powinna być odrzucana - zdecydowaliśmy nadać jej pełną moc, aby nie tylko przy posagach, lecz również we wszystkich innych sprawach ułożenie takiej stypulacji wywoływało skutek.

Niewywierająca z początku skutków prawnych stypulacja poprzez furtkę w postaci favor uxoris znajduje więc drogę do całkowitej skuteczności. Ewentualne niespełnienie się warunku mogło powodować roszczenie o zwrot bezpodstawnie uzyskanej kwoty przy użyciu condictio. Powyższy fragment nie jest jednak aż tak „opacznie” sformułowany, by nie można było zachować ważności przyrzeczenia nawet przy dawnym, restrykcyjnym zapatrywaniu się na condicio praepostera. Z literalnej interpretacji wynika bowiem, że statek mógł przybyć z Azji w dniu zawarcia stypulacji, która w takich okolicznościach miałaby znaczenie ,jeżeli statek dzisiaj przybędzie - przyrzekam dać dzisiaj”. Takiej możliwości interpretacji nie ma już jednak w greckiej parafrazie „Instytucji”, przypisywanej Teofilowi:

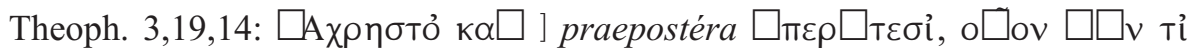

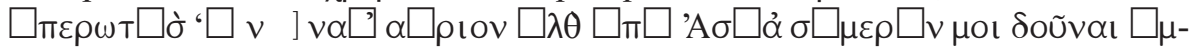

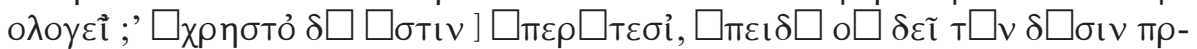

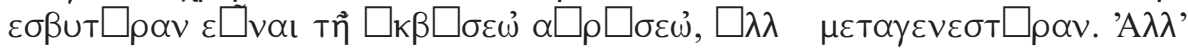

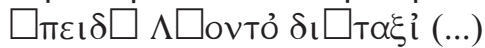

Bezwartościowe jest również i przyrzeczenie na opak. Gdyby ktoś wypowiedział formułę stypulacyjną w ten sposób: 'jeżeli statek przybędzie jutro z Azji, przyrzekasz dać mi dzisiaj?' - bezwartościowa będzie taka stypulacja, nie można bowiem wyprzedzać wypełnienia warunku wykonaniem zobowiązania, bo nie musi się on spełnić. Ale gdy konstytucja Leona (...)

Wyraz ,jutro" ( $\alpha \square \rho ı$ เov) zdecydowanie nie pozostawia wątpliwości, że mamy do czynienia ze stipulatio praepostera w pełnym tego słowa znaczeniu. 
W porównaniu do „Instytucji” Teofil w innych słowach przedstawia powód, dla którego przyrzeczenia takie były niedozwolone, jednak uzasadnienie opierające się na potencjalnym wypełnieniu zobowiązania zaciągniętego pod warunkiem wobec braku ziszczenia się treści zamieszczonej w klauzuli tego postanowienia umownego wcale nie jest przekonujące $\mathrm{z}$ ekonomicznego punktu widzenia. Być może chodziło tutaj o obawę przed zbyt dużą liczbą postępowań w drodze condictionis indebiti spowodowanych lekkomyślnością kontrahentów? Pozostała część tekstu powtarza za „Instytucjami” wzmiankę o zmianach ustawodawczych, zmierzających ku sanowaniu wadliwie zawartych stypulacji. Ciekawe byłoby rozważenie, jak stosowany był ten przepis w przypadku dodania klauzuli umownej w postaci sformułowanej w D. 18,6,8,1: sive navis ex Asia venerit sive non venerit. Wydaje się, że uzasadnienie zakazu opacznych stypulacji, wywodzące się z „Parafrazy”, dopuszczałoby możliwość dodania takiego warunku już przed wydaniem wzmiankowanych konstytucji cesarskich. Problematyczne pozostaje jednak sformułowanie „Instytucji”. Sądzę, że nawet zanim nastały czasy cesarza Leona, stypulacja taka byłaby dopuszczalna. Intuicyjnie bowiem juryści powinni byli dostrzec zupełny brak rationis legis dla utrzymania zakazu w mocy względem tego warunku, zwłaszcza po zapoznaniu się z dyskusją prowadzoną wśród jurystów klasycznych, której owocem była opinia Juliana powołana przez Paulusa w D. 18,6,8,1.

Ostatnim przypadkiem rozważań na temat błędnego zawarcia warunku $\mathrm{w}$ tekstach zawierających słowa si navis ex Asia venerit jest wyjątek $\mathrm{z}$ siedemdziesiątej czwartej księgi komentarza Paulusa do edyktu pretorskiego :

D. 44,7,44,2 (Paulus ks. 74 ad edictum praetoris): Condicio vero efficax est, quae in constituenda obligatione inseritur, non quae post perfectam eam ponitur, veluti 'Centum dare spondes, nisi navis ex Asia venerit?' sed hoc casu existente condicione locus erit exceptioni pacti conventi vel doli mali.

Warunkiem skutecznym jest ten, który jest wprowadzony przy zawieraniu zobowiązania, a nie po tym, kiedy stanie się ono kompletne, jak na przykład 'przyrzekasz dać sto, jeżeli statek nie przybędzie z Azji?’. W tym jednak przypadku po spełnieniu warunku będzie możliwe [przyznanie] exceptio pacti conventi lub doli mali.

Nieprawidłowości związane $\mathrm{z}$ dodaniem do umowy zastrzeżenia $\mathrm{w}$ postaci warunku nie są tu związane z samą jego treścią, ale z momentem, w którym zostało to dokonane. Złagodzenie reżimu zabraniającego dokonywania takich zastrzeżeń było do tego stopnia naturalne, że nie musiało zostać dokonane na mocy specjalnej konstytucji cesarskiej, jak to miało miejsce w przypadku con-

${ }^{132}$ Index interpolationum wskazuje, że fragment był być może kwestionowany w całości, a na pewno od słowa sed do końca. Zob. L. Mitteis, E. Levy, E. Rabel, Index Interpolationum..., Weimar 1935, t. 3, szp. 367. 
dicionis praeposterae, lecz w razie zaistnienia określonych okoliczności była stosowana po prostu ochrona prawa pretorskiego iuris civilis corrigendi gratia. Na marginesie warto dodać, że omawiany tekst jest jedynym, w którym interesujące nas słowa tworzą samodzielnie występujący warunek ujemny - nisi navis ex Asia venerit ${ }^{132}$.

Bezpośrednio z „Parafrazy”133 warunek przejęty został do kalabryjskiego podręcznika Prochiron Legum, który powstał w II połowie XII wieku po Chr. Słowa si navis ex Asia venerit są przekształcone wskutek dostosowania do nowych czasów, w których bardzo popularne były pielgrzymki do Ziemi Świętej.

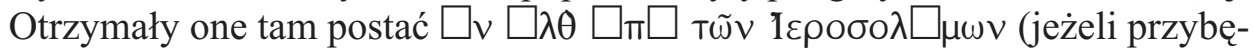
dzie z Jerozolimy $)^{134}$. Tak samo jak w „Parafrazie”"135, w greckiej wersji formuły następuje użycie bardzo popularnego ${ }^{136}$ trybu coniunctivus z partykułą $\square$ v, który był semantycznym odpowiednikiem indicativi futuri ${ }^{137}$.

Warunek si navis ex Asia venerit zrobił w tekstach jurystów rzymskich oszałamiającą karierę. Był tak charakterystyczny, że nawet dzieła średniowieczne czerpiące $z$ tradycji romanistycznej odwoływały się do niego. Jego popularność była z pewnością związana z odniesieniem do dziedziny życia, która dla rozwoju państwa rzymskiego była newralgiczna. Odniesienie to było główną przyczyną, dla której formuła warunku tak często powtarza się u wielu autorów. Niestety zbyt mało jest danych, aby stwierdzić, do jakiego stopnia wpływ na częstotliwość występowania słów naszego warunku miały czynniki socjologiczne, na przykład poczytność i autorytet jurystów, którzy używali go w początkowym okresie, a co za tym idzie - czy w głównej mierze „charyzma" tych jednostek zadecydowała o tak szerokiej jego recepcji.

Lektura tekstów zawierających formułę naszego warunku prowadzi do stwierdzenia, że był on wykorzystywany do przedstawiania zagadnień z wszystkich niemal dziedzin prawa - w tym także prawa procesowego ${ }^{138}$. Przybierał

${ }^{133}$ Por. F. Brandileone, V. Puntoni (ed.), Prochiron Legum pubblicato secondo il codice vaticano greco 845 , s. xiii.

${ }^{134}$ Proch. Leg. 25,4. Nie było to jedyne odniesienie do prawa rzymskiego poczynione w tym dziele. Zob. krótką recenzję Prochiron Legum autorstwa J. Burego, [w:] „The English Historical Review" 42 (1896), s. 349-352.

135 Theoph. 3,19,14. „Parafraza” przytacza słowa warunku również w języku łacińskim. Por. Theoph. 3,19,22.

${ }^{136}$ Jednym z najczęściej używających go autorów był Ksenofont.

${ }^{137}$ Podobieństwo z czasem przyszłym trybu oznajmującego było również morfologiczne. Coniunctivus z $\square v$ był używany w różnych typach zdań - nie tylko w warunkowych. Por. np. M. Auerbach, M. Golias, Gramatyka grecka, Warszawa 1985, s. 191.

${ }^{138}$ Obok warunku si Titius consul factus erit, w oparciu o fragment D. 35,1,21 został on wymieniony jako typowy przykład condicionis facti. Zob. C. Mokrejs, 'In der Schwebe'. Zum Versuch der Kategorisierung der conditio iuris im klassischen römischen Recht, RIDA 57 (2010), s. 317-318. 
on głównie postać zastrzeżenia zawieszającego, kazualnego i dodatniego. Jako samodzielny warunek ujemny występuje on tylko w jednym fragmencie „Digestów" - D. 44,7,44,2. Z analizy poszczególnych fragmentów wynikać może postulat ostrożnego wykorzystywania metody filologicznej do badań nad prawem rzymskim.

\title{
THE SI NAVIS EX ASIA VENERIT CONDITION IN THE ANTIQUITY AND THE MIDDLE AGES
}

\author{
S u m m a r y
}

The si navis ex Asia venerit condition made a spectacular career in the texts of Roman jurists. It was so characteristic that even the medieval works that drew on the Roman tradition had plenty of referrals to that condition. Its popularity was obviously connected with its reference to that sphere of life that was essential for the development of the Roman state. However, there is not enough data to allow determination to what extent the frequency of the reference to those words was influenced by sociological factors, or the authority of jurists whose words were quoted, and who referred to that condition. In other words, whether it was the 'charisma' of those authorities that played a decisive role in its wide reception and recognition.

The review of texts that contain the formula of the above condition allows us to formulate a thesis that the si navis ex Asia venerit condition was used to present issues from almost all areas of law, including the procedural law. It usually took the form of a suspending, casuistic and positive condition. It appeared only once as a negative condition (Digests 44,7,44,2). A careful analysis of individual fragments of the selected texts in which the condition did appear allows us to formulate a postulate that a philological method in the research into Roman law should be used with a substantial degree of caution.

\section{LA CONDITION SI NAVIS EX ASIA VENERIT À L'ANTIQUITÉ ET L'ÉPOQUE MÉDIÉVALE}

\section{$\mathrm{R}$ é $\mathrm{s}$ u $\mathrm{m}$ é}

La condition si navis ex Asia venerit connait un succès fou dans les textes des juristes romains. Elle est si particulière que même les œuvres moyenâgeuses qui puisaient dans la tradition romaniste, faisaient appel à celle-là. Sa popularité est sans doute liée aux références qu'elle fait à un domaine de vie névralgique pour le développement de 
l'État romain. Cette référence est la raison principale pour laquelle la formule de la condition revient si souvent dans les œuvres de différents auteurs. Malheureusement, nous ne disposons pas de nombre suffisant de données qui permettrait de constater à quel point les facteurs sociologiques impactaient la fréquence des mots de notre condition, ces facteurs étant par exemple la lecture et l'autorité des juristes qui l'avaient utilisée tout au début et, par la suite, nous ne pouvons pas dire si c'est notamment le « charisme » de ces individus qui a influé sur une réception aussi large de la formule.

La lecture des textes contenant la formule de notre condition nous amène à constater que cette dernière servait à présenter les questions relevant de quasiment tous les domaines du droit, y compris du droit processuel. Elle revêtit essentiellement la forme d'une clause suspensive, causale et positive. En tant que condition négative indépendante, elle n'apparaît que dans un fragment de Digest - D. 44,7,44,2. Un postulat pourrait résulter de l'analyse des fragments sélectionnés, il porte sur une utilisation prudente de la méthode philologique dans les études sur le droit romain. 